\title{
Social-ecological resilience in remote mountain communities: toward a novel framework for an interdisciplinary investigation
}

\author{
Rike Stotten $^{1}$, Lisa Ambrosi $^{2}$, Erich Tasser $^{3}$ and Georg Leitinger $^{2}$
}

\begin{abstract}
Globally, mountain areas are facing numerous social, economic, and ecological challenges. The interplay of natural and social factors makes them complex social-ecological systems. To investigate a mountain setting in the Austrian Alps, we developed the resilient livelihood framework (RLF), relying on the sustainable livelihood framework and integrating the community resilience and ecosystem services concepts. This novel RLF highlights the basic function of natural capital for economic, social, cultural, and political capital and displays the social valorization and demand of single-ecosystem services. The RLF serves to examine the social-ecological complexities with a set of drivers, capitals, livelihood strategies, and outcomes of two remote mountain villages, Obergurgl and Vent in the Upper Ötztal Valley (Tyrol, Austria). Here, qualitative and quantitative descriptions enable comprehensive insights into the complex interplay of the social and ecological spheres of both communities. Its output has been densified and calculated with a modified Shannon-Wiener Index that revealed a higher social-ecological resilience for the village of Vent than Obergurgl. The study bridges various disciplines and contributes to the theoretical and practical advancement of a resilience framework through the application to a case study site by combining ecological and sociological approaches. The application study can serve as a pilot for similar applications in remote mountain areas to support the decision making of local managers and stakeholders.
\end{abstract}

Key Words: community resilience; ecosystem services; forms of capital; Shannon-Wiener Index; sustainable rural livelihood framework

\section{INTRODUCTION}

\section{Background}

Although generally rich in natural and cultural resources, the economic development of mountain regions across the world has been lagging behind the development of lowlands for several centuries. Especially remote mountain communities in the developing countries of Asia, Africa, and Central and South America are still among the poorest in the world (Mishra 2002). The communities of the European Alps, however, have experienced rapid economic development, mainly driven by tourism in the 20th century (Barker 1982). Nevertheless, remote mountain communities in the European Alps are facing numerous social, economic, and ecological challenges. They have undergone substantial socioeconomic changes over the past decades, including a decrease in farms and farmland, especially in marginal areas, an overdependence on (winter) tourism as the main form of income, limited opportunities for education and skill development, and the outmigration of young people as well as the associated loss of social memory and cultural changes (Zucca 2006). Mountain areas are further disproportionally affected by natural hazards and climate change (Fuchs 2009, Luthe et al. 2012). Even if farming was the basis for livelihood in those communities for many centuries, it has been replaced by tourism in the 20th century (Wilson et al. 2018). Nevertheless, agriculture provides several functions that are crucial for rural communities, especially regarding tourism. These include the preservation of landscape, the provision of ecosystem services (ES), and the positive impact on social cohesion and other economic activities (van der Ploeg et al. 2000, Flury et al. 2013).

The interplay of natural factors and social drivers makes remote mountain communities complex social-ecological systems (SES) that have multiple characteristics and are challenging to understand: "they are cross- or multiscale, multidisciplinary, dynamic ..., subject to behavioral uncertainty, involve nonlinear relationships and hence thresholds or tipping points, and have emergent and embedded properties" (Dorward 2014). Here, the feedback between social and ecological patterns and processes defines social-ecological systems and vice versa, as bridging natural and social sciences has led to the development of socialecological system approaches (Plummer and Armitage 2007 and references therein). It is challenging to elaborate hybrid and pluralistic frameworks that integrate social and ecological science aspirations to examine and evaluate the resilience of such SES (Miller et al. 2010). As an example, the social science-oriented sustainable rural livelihood (SRL) framework strives for a holistic approach to investigating less-favored communities and the complexities of poverty (Morse and McNamara 2013). It combines participatory, bottom-up approaches with recognition of the impact of macro-level governance, policies, and institutions (Small 2007). Within this framework, a livelihood can be considered sustainable, if it can cope with and recover from stresses, shocks, and seasonality and maintain or enhance its capabilities and assets both now and in the future (Carney 1998). However, the SRL framework has been criticized for several weaknesses, including a lack of emphasis on ecological elements (Dorward 2014) and a fuzzy integration of concepts like "sustainability" and "resilience" (Small 2007). Others criticize the economic perspective within the SRL approach (Acre 2003, De Haan 2012). Originally, the SRL served to shed light on the complexity of poverty and was mainly applied in the Global South. We are convinced, however, that while addressing the mentioned criticism it is a valuable framework for examining the complexities of remote mountain communities in the Global North in comparatively less globalized areas. Drawing on a field study conducted in two remote villages of the Ötz Valley in the

${ }^{1}$ University of Innsbruck, Department of Sociology, ${ }^{2}$ University of Innsbruck, Department of Ecology, ${ }^{3}$ Eurac Research, Institute for Alpine Environment 
Austrian Alps, we aim to provide insights into the interplay of tourism and farming within the SES and the provision of ecosystem services (ES). Finally, we demonstrate how this interplay affects the social-ecological resilience of remote mountain communities. For this purpose, we introduce a novel conceptual framework based on the SRL framework by integrating the concepts of community resilience and ES. Relying on a normative understanding of resilience that designates resilience as a desirable state, we aim to integrate into this novel conceptual framework positivist (social-ecological) and constructivist (social) resilience approaches (see Wilson 2018). Based on this novel framework, we reveal characteristics that contribute to the resilience of the communities at the case study sites, especially examining tourism and farming activities, and highlight the local provision of ES.

\section{Conceptual framework}

The SRL framework organizes the factors that limit or enhance livelihood opportunities and reveals their complex interdependencies. Here, sustainable livelihoods are achieved through access to a range of livelihood resources (capitals) that are combined in the pursuit of various livelihood strategies, e.g., agricultural intensification or marginalization. Consequently, the livelihood strategies lead to different outcomes that feedback on the resources. In homogeneous communities, livelihoods are diverse and dynamic to survive and improve the standards of living (Ellis 1998). The livelihood strategies are "negotiated results of interactions between individuals and households and the world around them" (Small 2007:35). The SRL framework considers multiple available capitals that are faced with the vulnerability context including trends, shocks, and seasonality. Originally, Scoones (1998) distinguished five different capitals: human, natural, financial, physical, and social. The SRL has been widely applied in development projects in the Global South (see Farrington et al. 1999, New Zealand Nature Institute 2006, Scoones 2015), as well as in scientific investigations (Daskon and Binns 2010, Jacobs and Makaudze 2012, Tang et al. 2013). Dorward (2014), however, criticized the lack of emphasis on ecological elements and other socioeconomic issues such as markets, institutions, and politics. Others fault the economic perspective within the SRL approach and consider social and other capitals only with regard to how to mobilize economic capital (Acre 2003, De Haan 2012). Scoones (2009) admitted to missing theoretical ground in the SRL framework, resulting in a fuzzy integration of concepts like "sustainability" and "resilience" (Small 2007). Additionally, the term sustainability today seems to have been superseded by the resilience thinking approach as the essential concept for rural development (Freshwater 2015) because it captures dynamic aspects of a system better than the outcome-focused concept of sustainability (Park et al. 2013). We further rely on the resilience concept, deriving from mathematical sciences to describe dynamic systems, elaborated by ecologists (Davidson 2010), which has also become popular among social scientists (Adger 2000, Magis 2010, Wilson 2012a, Maclean et al. 2014). The broadly accepted definition of resilience "is the capacity of a system to absorb disturbance and reorganize while undergoing change so as to still retain essentially the same function, structure, identity, and feedbacks" (Walker et al. 2004).

\section{MATERIALS AND METHODS}

Toward a novel framework for an interdisciplinary investigation To enable evaluation of an SES, we integrated the social resilience concept of community resilience with ecological aspects within the SRL. Social-ecological resilience explicitly includes adaptability and transformability, implying that a system does not necessarily have one or more equilibrium states. Instead, it adapts and changes continuously (Folke et al. 2010, Davoudi et al. 2012). Also, trends, shocks, and seasonality, which might appear as fast-onset natural disturbances (e.g., weather-related and geological disasters) or as slow-onset anthropogenic disturbances (e.g., human-environmental mismanagement, sociopolitical disturbances, economic disturbances, or disturbances linked to globalization processes) are considered in the concept of social-ecological resilience (Wilson 2012a).

Regarding the conceptualization of social-ecological resilience on a community scale, we refer mainly to Wilson $(2012 a, b)$. The concept of community resilience builds on two previously existing concepts: capital by the French sociologist Bourdieu (2016) and the sustainable development concept (Baker 2007). Sustainable development is based on the three pillars of social, environmental, and economic issues, whereas capital refers to "accumulated labour in its materialized form or its 'incorporated', embodied form" (Bourdieu 1986:241). The three forms of capital, namely social, economic, and cultural capital, have been supplemented with political and environmental capital (Bourdieu 1986). Without claiming to be holistic, this set of capitals encompasses a broad range of factors, influencing community resilience. However, other authors follow other capital constellations (Emery and Flora 2006, Magis 2010, Wilson 2012b). In our understanding, economic capital refers to the financial resources of the community and its households as well as the existing built infrastructure (Wilson 2010) and the embeddedness of the economic activities into the global capitalist market (Kelly et al. 2015). Social capital "include[s] levels of interaction between community members such as trust, relationships, conflict resolution processes, engagement of young and old people, learning and communication pathways, cooperation, strength of networks, bonding and bridging capitals as well as community "cohesiveness"' (Kelly et al. 2015:13). Furthermore, cultural capital reflects rites, traditions, language, taboos, norms, and convention; it represents "the way people 'know the world' and how they act within it" (Emery and Flora 2006:21). Also, the socio-cultural identity of community members, shaped by the self-conception and self-perception as part of social groups that have their own distinct culture (Warren et al. 2016), is reflected in the cultural capital. Furthermore, political capital refers to the political context, such as governance structures, leadership, power, institutional rigidity, transparency of decision making, political participation, the role of media, and corruption. Finally, natural capital covers aspects such as climate, topography, land cover, biodiversity, and natural beauty (Emery and Flora 2006). To demonstrate resilience at the community level it is crucial to understand the complex interplay of economic, social, cultural, political, and natural capitals (Emery and Flora 2006, Kelly et al. 2015). Building on this, communities are resilient when the five capitals are well developed (Kelly et al. 2015). However, one or more weakly developed capitals raise the vulnerability of the community, which is understood here as the antithesis of 
Fig. 1. Resilient livelihood framework (RLF) to evaluate the resilience of socialecological systems by combining sustainable rural livelihoods and ecosystem service (ES) concepts.

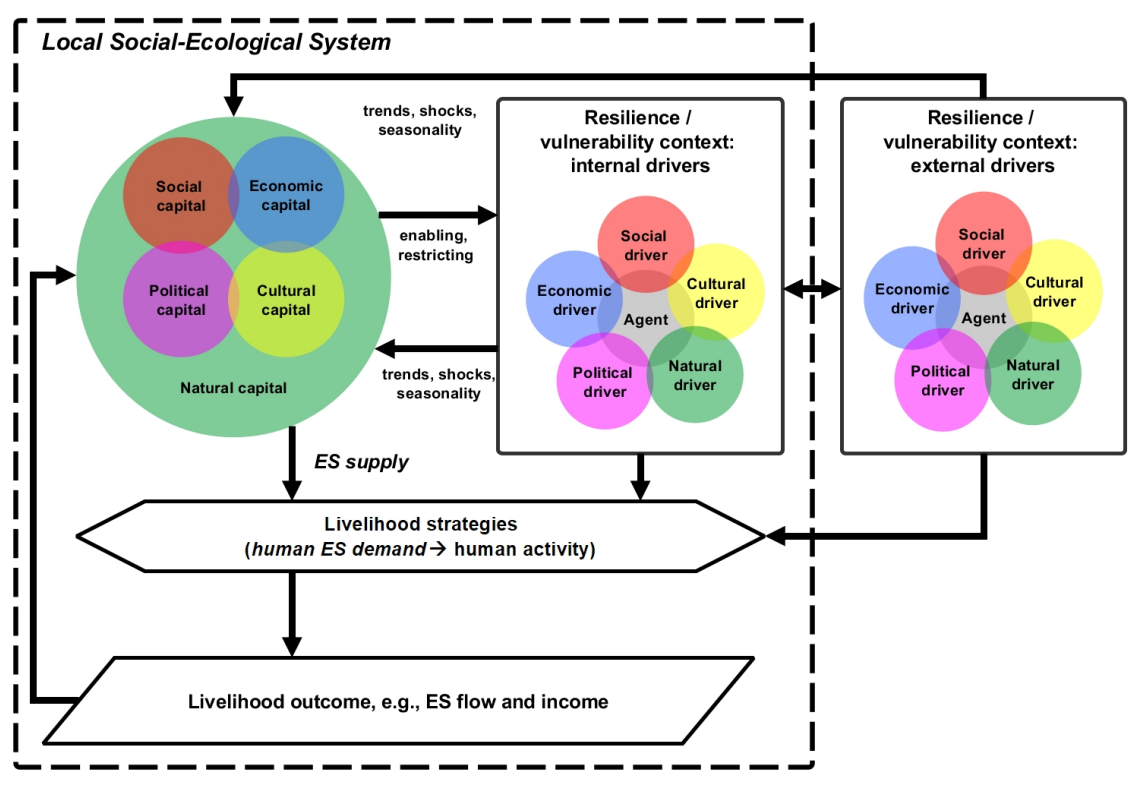

resilience (Wilson 2012a). Cumming et al. (2005:978) further argue that "if system identity is maintained over the time horizon of interest under specified conditions and perturbations, we can term the system resilient" (see also Carpenter et al. 2001). Thus, an SES is resilient when the single factors (capitals, livelihood strategies, livelihood outcomes, ES) remain relatively stable so that the SES can maintain the same identity shaped by the five capitals. However, drawing the line between an identity remaining stable and changing identities can be fuzzy and is based on a subjective interpretation (Walker et al. 2004).

In addition to the combination of the SRL and the concept of community resilience, the natural and ecological aspects were given a greater role in the framework. As suggested by Costanza et al. (2014), all capitals were embedded in the natural capital because it provides the environment in which the other capitals sit. Furthermore, we also integrated the ES concept (de Groot et al. 2002, Millennium Ecosystem Assessment 2005). Here, we follow the differentiation between supply, demand, and flow as described by Burkhard and Maes (2017) and Villamagna et al. (2013) and we distinguish between (1) the capacity of ecosystems to provide ES (ES provision or supply), (2) the demand for ES (ES demand), and (3) their actual use (ES flow). This is a special prerequisite for evaluating the resilience of SES by considering each chain link in the ES delivery process within the SES.

The newly developed resilient livelihood framework (see Fig. 1) integrates the SRL framework with the concepts of community resilience and ES to better understand the interlinkages of farming and tourism as well as their impacts on the SES. It conceptually illustrates the state of an SES and demonstrates its influencing dynamics. Within the framework, the social, economic, political, cultural, and natural capitals characterize stocks of assets. The external and internal drivers represent everything influencing these capitals. External drivers forwarded by agents represent broader conditions on the global and regional scale and shape the external context for vulnerabilities and resilience. Economic and political drivers, including governance and institutions, encompass markets (Dorward et al. 2003). A cultural driver is the current approach of UNESCO to protect tangible and intangible cultural heritage (Vecco 2010); the EU LEADER program fosters social capital building (Rivera et al. 2018) and is a social driver. Political drivers, or transformative structures and processes, as originally named in the SRL framework, represent various levels of government as well as laws, policies, incentives, and institutions (Scoones 1998). Natural drivers are an integral part of human-environment interactions that have a direct impact on society or are perceived as such by society (Forbes et al. 2009), such as climate change or ongoing biodiversity loss. The agent-based internal drivers are dynamic capabilities influenced by external drivers and rely on the capitals to react. They shape the internal context for resilience and vulnerabilities and thus facilitate or hinder community capital building (Fischer and McKee 2017). Through the interaction with the economic, social, cultural, and political capital, the natural capital can provide ES (potential ES supply; Costanza et al. 2014). Influenced by the status of the capitals and by internal and external drivers, residents decide on various livelihood strategies, i.e., they decide how to use their capitals to generate specific ES flow and income. These livelihood strategies are expressed as desires for certain ES (ES demand) that lead to specific actions or activities to enhance the supply or to "harvest" the desired ES. The resulting livelihood outcome includes ES flow or income. ES flows and incomes in turn influence the capital; this can trigger changes in the livelihood strategy and livelihood outcomes in a subsequent period. 
Fig. 2. Overview of case study sites, land use, and land cover as of 2015 (adapted from Huber et al. 2020).

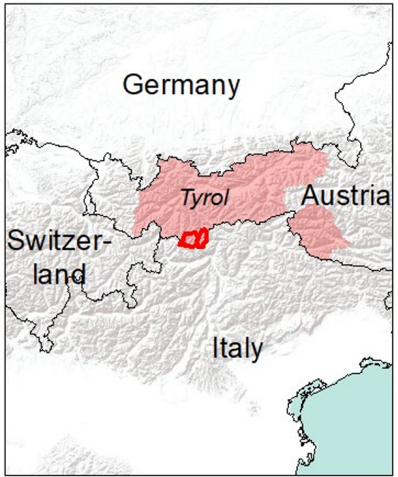

ski area 2011

$\nabla$ IUCN protected area 2015

Sources: Esri, USGS, NOAA.
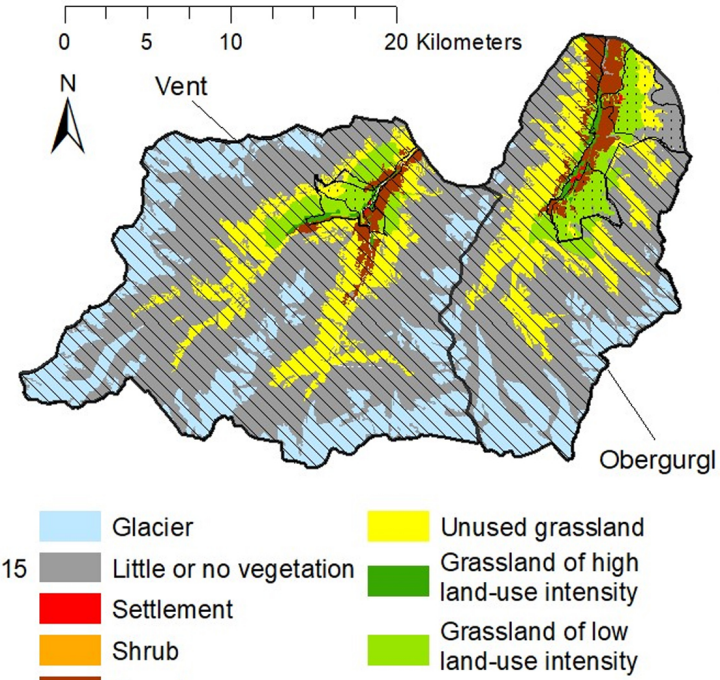

\section{Study sites}

This framework served to empirically investigate the case study sites of two remote mountain communities, namely Obergurgl and Vent (Fig. 2). Obergurgl and Vent are two Alpine villages in the municipality of Sölden in the Upper Ötz Valley (Tyrol, Austria) with a population of 509 and 138, respectively (Statistik Austria 2017). At the end of the 18th century, the economy in both villages was based on animal husbandry and residents were mainly subsistence farmers. However, the population decreased as food shortages forced migration. A modernization process, brought about by tourism development in the Alps, initiated economic recovery, especially in the village of Obergurgl(Meleghy et al. 1985). Although Obergurgl has developed as a center for mass winter tourism in the Alps, the neighboring village of Vent positioned itself as a classified mountaineering village for "soft tourism" that strives to reduce the destructive character of mass tourism (Fischer 2014). Both communities have faced substantial socioeconomic change over the past decades, such as the decline in farming to a recent dependency on tourism as the main source of livelihood, which makes them suitable case studies for an investigation of their social-ecological resilience.

\section{Practical implementation and data collection methods}

We applied various methods of qualitative and quantitative social research as well as ecological approaches. Finally, all the results are condensed in an evaluation of the social-ecological resilience of the selected communities.

\section{Qualitative data collection}

To draw an image of economic, social, cultural, political, and natural capital as well as its drivers in each village, semi-structured expert interviews were conducted. Such interviews are open structured to gain a broad range of information and knowledge as well as to acquire access to the expert's tacit knowledge. For our purposes, an expert is a person with specific knowledge in a certain field of activity and who functions as a representative of a group (Bogner et al. 2014). Between October 2017 and June 2018 we conducted 20 interviews (Table 1) with local actors from both villages as well as with regional stakeholders. Each interview lasted 30-100 minutes. The local interviewees were selected with a view to gender, age group, immigrant status, and role in the community. Issues like farming, tourism, village development, social cohesion, and local disturbances were addressed during the interviews, but also additional aspects were mentioned by the interviewees. A verbatim transcript of the expert interviews served to transform spoken material into written form. For data evaluation, we applied qualitative content analysis (Mayring 2007). This systematic, rule-guided, and theoretically grounded step-by-step approach to qualitative text analysis is based on the inductive development of categories close to the given text material and the application of deductive verification of those categories regarding the research questions and theory. For development of the categories, the software ATLAS.ti was used to organize and code the text material (Konopásek 2011). Finally, 52 inductively developed categories were deductively grouped into the five domains of the community resilience concept. The acquired knowledge has been enriched with additional documented analyses of development concepts and laws (Hoffmann 2018).

\section{Quantitative data collection}

The perception of the actual contribution of the local landscape to certain ES and their importance for the communities were investigated among the inhabitants. From March to August 2018, questionnaires with closed questions for self-completion (Paier 2010) were distributed personally in Vent and Obergurgl. In total, 40 persons ( $27 \%$ of all local inhabitants) took part in the survey in Vent, and 66 persons (13\% of the inhabitants) in Obergurgl (see Gruber 2019). These results were tested with the MannWhitney U test in the present study. The Mann-Whitney U tests were conducted with SPSS statistics, version 26 (IBM Corporation). 
Table 1. Stakeholders selected for expert interviews.

\begin{tabular}{lccc}
\hline \hline Interviewees (double occupation) & Vent & Obergurgl & Regional \\
\hline Farmer & 2 & 2 & \\
Accommodation provider & 6 & 6 & \\
Lift company manager & 1 & 1 & \\
Local business owner & 2 & 1 & \\
Member of municipal council & & 3 & \\
Mayor & & & 1 \\
Local historian & & 1 \\
Nature park manager & & 1 \\
Scientist from the MAB study & & &
\end{tabular}

\section{Habitat mapping and settlement activities}

Because many of the ES models are based on land use/land cover maps, we first mapped habitats for the case study site for several historical dates: 1860, 1950, 1970, 2000, and 2015. For each time period, historical maps and orthophotos were analyzed following a methodical approach for standardized landscape studies in small dimensions (Tasser et al. 2009). The Francisco-Josephinian Cartographical Register from 1860 marks the start of spatially explicit historical land use/cover. With it, various land use/cover types (e.g., forest, meadows, pastures, and settlements), as well as specific landscape features (e.g., rivers and rocks), were mapped. For 1950 and 1970, we used georectified aerial photographs, and for 2000 and 2015, we consulted the orthophotos. All data were mapped and referenced in a geographic information system, whereby only areas greater than four hectares were considered. To evaluate settlement activities, the habitat type "settlement area" was classified and individual buildings were evaluated. For this purpose, all buildings (e.g., houses, stables, huts) with a roof area of more than $16 \mathrm{~m}^{2}$ were counted for each historical time step.

\section{Beef production}

In a first step, fodder production was calculated based on a biophysical model and the mapped area of used grassland from the five historical years (see habitat mapping above). Quantification of the potential yields was calculated via yield functions based on the length of the growing season. Yields were refined according to site parameters such as precipitation during the growing season and solar radiation (for more details, see Jäger et al. 2020). In the second step, the grassland yield was derived from the production by considering feed quality in the form of metabolic energy content (megajoules MJ ME) and yield losses (for extensively used pastures and meadows: $-53 \%$; for intensively used meadows: $-43 \%$ ). We estimated the potential number of bovines that can be kept based on the harvested forage energy (energy demand per bovine: 35,251.9 MJ ME/a). In the third step, we estimated the potential quantity of beef produced as the ES flow. The quantity was calculated considering herd composition, average live weight, average slaughter age, and the resulting quantity of meat (boneless) per year (see Table 2).

\section{Land management}

To evaluate the share of protected areas in the case study sites, the extent of the protected areas according to the European Environment Agency (2015) was analyzed in ArcGIS. The extent of the sealed area was estimated based on the habitat type "settlement area" and the number of individual buildings was provided by Sulzer (2018). Furthermore, the extent of the paved road network was provided by Schirpke et al. (2019). For the individual buildings, a mean extent of $600 \mathrm{~m}^{2}$ of sealed soil per building was assumed, based on the visual inspection of 20 random samples from Obergurgl and Vent in the orthophotos of 2015. For the asphalted roads, a mean width of $7 \mathrm{~m}$ was assumed.

\section{Water supply}

We approximated naturally available water from the runoff in the main creeks "Venter Ache" in Vent and "Gurgler Ache" in Obergurgl. Gauge measurements of runoff were available for Venter Ache and Gurgler Ache from 1966 and 1976 until 31 December 2015. We calculated the total runoff for every year and estimated an average runoff for 1970 (by taking the mean for 1968-1972), for 2000 (mean 1998-2002), and for 2015 (mean 2011-2015).

\section{Statistical methods of resilience evaluation}

Based on the livelihood strategies, the livelihood outcome feeds back on the individual capitals (Fig. 1). To illustratively evaluate the resilience of the investigated SES (see Table 3), the impact of given livelihood strategies and outcomes on the capitals was assessed based on a subjective résumé of our gained knowledge. As a common simplification, a weakly developed capital weakens the resilience (see Cumming et al. 2005). A strongly developed capital is considered positive for resilience. Consequently, we considered a system to be strongly resilient if all capitals are at a relatively high level and more or less balanced (see Adger 2000) and if the prevailing livelihood strategies contribute to a further strengthening of the capital (livelihood outcome). To measure the diversity of items (i.e., capitals) and their proportional abundances $\left(p_{i}\right)$, the Shannon-Wiener index $\left(H^{\prime}\right)$ was used (Spellerberg and Fedor 2003):

$$
H^{\prime}=-\sum_{i=1}^{R} p_{i} \ln p_{i}
$$

Here, $p_{i}$ is calculated by multiplying the capitals with the effects of the strategies and standardizing them in comparison to a "best case situation," i.e., a highly positive capital multiplied with a highly positive strategy $(0.9 \times 0.9)$. More precisely, for a final evaluation of the social-ecological resilience of both villages, we assigned mean class values from 0.1 to 0.9 to the status of the capitals and the influence of the livelihood strategies on the capitals. Using this modification of the calculation method for $\mathrm{p}_{\mathrm{i}}$ we ensure that the index takes the value 1 when all capitals are equally at a high level and are equally further increased by the livelihood strategies. The H' index $(\min =0)$ is lower when the capitals are less equal and becomes lower when the livelihood strategies (1) lower all capitals or/and (2) lead to less balanced capitals. Therefore, also trade-offs between the livelihood outcomes are indicated.

\section{RESULTS OF APPLICATION OF THE FRAMEWORK}

With application of our resilient livelihood framework (RLF), we investigated the social-ecological systems of Vent and Obergurgl. The results are presented below according to the novel framework (see Fig. 1).

\section{External and internal drivers influencing the capital}

During the expert interviews, the local and regional stakeholders mentioned only a few external drivers within the resilience- 
Table 2. Development of the permanent grassland production, the grassland energy yield, the resulting fodder potential for bovines, and the produced beef as ecosystem services (ES) flows for the villages of Vent and Obergurgl.

\begin{tabular}{|c|c|c|c|c|c|c|c|c|}
\hline \multirow[b]{2}{*}{ Year } & \multicolumn{2}{|c|}{$\begin{array}{c}\text { Grassland } \\
\text { production }(\mathrm{t})\end{array}$} & \multicolumn{2}{|c|}{$\begin{array}{c}\text { Grassland yield } \\
\left(10^{3} \mathrm{MJ} \mathrm{ME}\right)\end{array}$} & \multicolumn{2}{|c|}{$\begin{array}{l}\text { Potential number } \\
\text { of bovines (n) }\end{array}$} & \multicolumn{2}{|c|}{ Potential beef production $(\mathrm{t})$} \\
\hline & Vent & Obergurgl & Vent & Obergurgl & Vent & Obergurgl & Vent & Obergurgl \\
\hline 1860 & $3,449.2$ & $6,103.3$ & $12,147.8$ & $21,495.5$ & 344.6 & 609.9 & 28.2 & 49.9 \\
\hline 1950 & $1,975.7$ & $3,773.4$ & $6,958.5$ & $13,289.7$ & 188.1 & 359.3 & 15.4 & 29.4 \\
\hline 1970 & $1,575.6$ & $2,087.9$ & $5,549.3$ & $7,353.6$ & 124.4 & 164.8 & 10.2 & 13.5 \\
\hline 2000 & $1,410.3$ & $2,127.0$ & $4,967.1$ & $7,491.1$ & 113.6 & 171.3 & 9.3 & 14.0 \\
\hline 2015 & $1,360.6$ & $2,096.5$ & $4,792.0$ & $7,383.8$ & 96.9 & 149.3 & 7.9 & 12.2 \\
\hline
\end{tabular}

vulnerability context that influence the internal drivers as well as capitals; they presented themselves as detached from the phenomenon of external trends, shocks, and seasonality. Therefore, economic, social, cultural, political, and natural external drivers are presented for both villages.

Economically, neither Obergurgl nor Vent has been concerned by external drivers such as the bovine spongiform encephalopathy (BSE) crisis in the 1990s, the global financial crisis in 2008, or the drop in the European milk price in 2015. Also, stakeholders did not mention any effect of Brexit on the local economy, even though British tourists make up a large share of Obergurgl's clientele. Farmers in both villages have multiple incomes, so they see themselves as negligibly affected by the EU's Common Agricultural Policy. However, the industrialization of gastronomy in the 1970s reduced the traditional exchange relations between farms and hotels because of regulations (e.g., hygiene), low production volumes, and high production costs.

The social cohesion of both local communities is affected by immigration; however, it affects Obergurgl more than Vent. Most of the seasonal workers in both villages come from countries with diverse cultural backgrounds, e.g., southeastern Europe, and bring their values. Because foreign seasonal workers constitute more than half of the residents during the season, they affect the local communities. Additionally, some years ago foreign investors took over family-owned hotels in Obergurgl, where succession within the family was not given. Also, these stakeholders bring new attitudes and values to their hotels and the local community. Furthermore, it is difficult for immigrants (as well as Austrians from other parts of Austria) to become integrated in the community. This has negatively affected social cohesion in Obergurgl and Vent. Furthermore, cultural capital is threatened by the rising mobility that allows residents to join clubs and organizations outside the village, for example. Consequently, local clubs and organizations suffer a lack of members and therefore risk losing traditional knowledge and capacities. Further external drivers include rules made by the Tyrolean state government, for example, those concerning awarding water concessions and strict rules on the amount of residual water in each tributary (Amt der Tiroler Landesregierung 2017). Moreover, with the scope of implementation of the Austrian Spatial Development Concept (ÖREK), Tyrol has developed regional spatial programs and strategies that affect, inter alia, the development of tourist facilities, and the preservation of agricultural and green areas (Gruber et al. 2018). In Obergurgl and Vent, a protected area ("Ruhegebiet Ötztaler Alpen" since 1981, additionally classified as a Natura 2000 site in 1995 and as a nature park in 2006) exists adjacent to a ski resort. The Tyrolean Nature Conservation Act explicitly prohibits the construction of roads for public use and lifts ( $\$ 11$ TNSchG 2005), and the additional classification as a Natura 2000 site according to the Habitats Directive (Art 6.2) and the Birds Directive (Art 4.4.) specifically calls for refraining from any actions that have any, direct or indirect, negative impact on the ecological structure and functions of the protected habitats. Hence, touristic use of protected areas is limited to activities that require only low infrastructure, such as hiking, ski touring, or snowshoe hiking.

The internal drivers influencing the economic, social, cultural, political, and natural capital strongly affect the capitals and are thus related to them. In order to not be repetitive, they are presented in detail for both villages in Appendix 1.

\section{Capitals of the social-ecological system}

Here we extrapolate the influence of the drivers on the respective forms of capital and thereby evaluate the strength of the capital. Obergurgl focuses primarily on winter tourism, which demands financial capital for investments in infrastructure. Farming has lost its economic importance and is not integrated in tourism activities. However, as one regional expert stated "Those farmers, who were lucky to inherit properties in favorable locations have high monthly incomes, especially in Obergurgl," which results in a tendency for the socio-cultural identity to shift from being farmers to being landowners. Obergurgl has strong economic capital (see Table 3), because tourism brings multiple and high incomes and has hardly been affected by external drivers. The economy in Vent is also largely unaffected by external drivers, but in contrast to Obergurgl the financial investments in tourism infrastructure are small, as the following statement highlights: "Higher up we have a very long drag lift and it will be an important step for the coming years to replace it with a second-hand chairlift " (local expert). Vent has a balanced tourist season, which creates relatively stable use of infrastructure and the need for labor. Farming has also lost its economic importance. However, it is integrated in tourism activities. In sum, Vent's economic capital is evaluated as being only moderate (see Table 3). Considering the social domain, Obergurgl suffers from seasonal outmigration of residents that weakens social cohesion and has an impact on daily village life, which is underlined by the following statement made by a local expert: "I think that people in long phases of prosperity, as in Obergurgl, tend to this egotistic, greedy behavior." In Vent, it is the population size that endangers social cohesion, because it influences the maintenance of infrastructure and clubs and 
Table 3. An illustrative summary of the effects of the livelihood strategies on the mean class status of the capitals as the basis for the evaluation of resilience for Obergurgl and Vent. Key: $++(0.9)$ highly positive, $+(0.7)$ positive, o $(0.5)$ neutral, - $(0.3)$ negative, and - (0.1) highly negative impact of the strategy on the respective capital.

\begin{tabular}{|c|c|c|c|c|c|c|c|c|c|c|}
\hline \multirow[b]{2}{*}{ Capital } & \multicolumn{2}{|c|}{ Capital status } & \multicolumn{2}{|c|}{$\begin{array}{c}\text { Agricultural strategy } \\
\text { (maintaining traditional } \\
\text { use) }\end{array}$} & \multicolumn{2}{|c|}{$\begin{array}{l}\text { Touristic strategy (gentle } \\
\text { tourism) }\end{array}$} & \multicolumn{2}{|c|}{$\begin{array}{c}\text { Land management } \\
\text { strategy } \\
\text { (landscape preservation) }\end{array}$} & \multicolumn{2}{|c|}{$\begin{array}{l}\text { Water use strategy (unlimited } \\
\text { use) }\end{array}$} \\
\hline & Obergurgl & Vent & Obergurgl & Vent & Obergurgl & Vent & Obergurgl & Vent & Obergurgl & Vent \\
\hline Economic & $++(0.9)$ & $0(0.5)$ & $0(0.5)$ & $0(0.5)$ & $++(0.9)$ & $+(0.7)$ & $+(0.7)$ & $0(0.5)$ & $+(0.7)$ & $+(0.7)$ \\
\hline Social & $0(0.5)$ & $0(0.5)$ & $-(0.3)$ & $+(0.7)$ & $-(0.3)$ & $+(0.7)$ & $0 /-(0.4)$ & $+(0.7)$ & $0(0.5)$ & $0(0.5)$ \\
\hline Cultural & $+(0.7)$ & $+(0.7)$ & $--(0.1)$ & $++(0.9)$ & $+(0.7)$ & $+(0.7)$ & $-(0.3)$ & $+(0.7)$ & $+(0.7)$ & $0(0.5)$ \\
\hline Political & $+(0.7)$ & $0(0.5)$ & $0(0.5)$ & $0(0.5)$ & $++(0.9)$ & $0(0.5)$ & $0 /-(0.4)$ & $0 /-(0.4)$ & $0(0.5)$ & $0(0.5)$ \\
\hline \multirow[t]{2}{*}{ Natural } & $+(0.7)$ & $++(0.9)$ & $-(0.3)$ & $+(0.7)$ & $-(0.3)$ & $+(0.7)$ & $-(0.3)$ & $+(0.7)$ & $-(0.3)$ & $0(0.5)$ \\
\hline & Tot & effect $\left(H^{\prime}\right)$ & $0(0.44)$ & $+(0.64)$ & $+(0.62)$ & $+(0.64)$ & $0(0.50)$ & $+(0.61)$ & $0(0.58)$ & $0(0.57)$ \\
\hline \multicolumn{3}{|c|}{$\begin{array}{r}\text { Social-ecological resilience regarding } \\
\text { investigated strategies }\end{array}$} & & \multicolumn{7}{|c|}{ Obergurgl: 0.535 ( \pm 8.1 s.d.), Vent: 0.615 ( \pm 3.3 s.d.) } \\
\hline
\end{tabular}

organizations. However, cohesion among the new generation of hotel owners is strong, as the following comment underlines: "I recognize a positive attitude among the young people and most of them are motivated to work together" (local expert). Therefore, the social capital in Vent and Obergurgl is assessed to be only moderately developed (see Table 3 ). With reference to cultural aspects, in Obergurgl the inhabitants' socio-cultural identity risks taking on a service provider habitus that is becoming increasingly alienated from farming. Cultural festivities are important for the residents and are not marketed for tourism purposes. Vent demonstrates lively cultural traditions from sheep breeding and the transhumance of sheep from South Tyrol that play a major role here in the socio-cultural farming identity, as pointed out by a regional expert: "The close connection to the South Tyrolean valleys, especially to the Schnals Valley, is part of the identity in Vent." Therefore, the cultural capital is assessed as being stronger in Vent than in Obergurgl (see Table 3). Politically, individual residents of Obergurgl belonging to one extended family clan are well-integrated in and well-connected to several state institutions and hold political power. Also, Obergurgl is well represented at the municipal level, as is Vent. However, Vent is less well represented at the regional level. This suggests that Obergurgl's political capital is stronger than is Vent's (see Table 3). Considering environmental issues, in Obergurgl economic goals have so far enjoyed higher priority than have ecological goals, and expansion of the human living and economic space is given priority. Vent strives for more sustainable development in line with environmental issues. Therefore, Vent's natural capital is stronger than is that of Obergurgl (see Table 3).

Although the questionnaire survey revealed similarities among residents of Obergurgl and Vent in the perceived supply of ES (Fig. 3), significant differences in the assessment between the two villages were demonstrated for the ES "Protection from hazards" ( $p=0.045)$, "Providing habitats for pollinators" $(p=0.009)$, and "Maintaining biodiversity" ( $p=0.023)$; the perceived ES supply in Vent is higher for each service, which underlines the stronger natural capital in Vent.

\section{Livelihood strategies (human activity) and outcome}

Relying on the external and internal drivers and the resulting shapes of capital, the populations of Obergurgl and Vent construct their livelihood strategies by considering certain strengths and weaknesses of their community. We investigated four of the main livelihood strategies (see Fig. 1) in Vent and Obergurgl: agricultural strategy, touristic strategy, land management strategy, water use strategy (Table 4).

Fig. 3. Mean perceived ecosystem service (ES) supply based on the existing natural capital of the most relevant ES in the study areas. Values range from 1 (not important) to 4 (very important). Ecosystem services were classified according to CICES (Haines-Young and Potschin 2018).

\section{Provisioning ES}

Provisioning of clean water Agricultural food production Pasture and fodder production Raw material production (timber) Energy generation

Regulation \& Maintenance ES Protection from hazards Maintaining diversity Providing habitats for pollinators Provision of habitats Positive effect on the climate Improving air quality

\section{Cultural ES}

Opportunities for leisure activities Aesthetic inspiration Conservation of old breeds

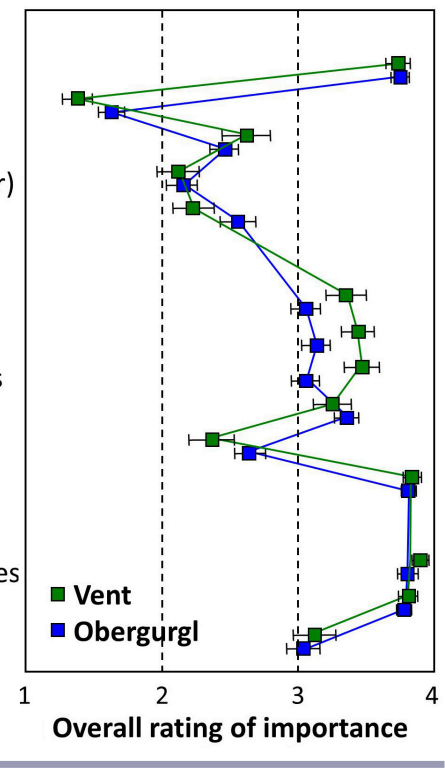

\section{Agricultural strategy and outcome}

Agricultural activities have declined in both Obergurgl and Vent, because they have lost economic significance in comparison to tourism activities. This can be seen in the number of farms that dropped from full-time to part-time operation: in the whole municipality of Sölden, 106 full-time and 86 part-time farms were counted in 1970, but only 14 full-time and 157 part-time farms were counted in 2010 (Tasser et al. 2013). Obergurgl had 20 farms in 1990, which decreased to 14 in 2016. In contrast, the number 
Table 4. Livelihood outcome presented as ecosystem services (ES) flows.

\begin{tabular}{|c|c|c|c|c|c|c|c|c|c|c|c|c|}
\hline \multirow{3}{*}{$\begin{array}{l}\text { Example } \\
\text { Year }\end{array}$} & \multirow{2}{*}{\multicolumn{2}{|c|}{$\begin{array}{l}\text { Agricultural strategy } \\
\text { Beef meat production } \\
\text { (t) }\end{array}$}} & \multicolumn{4}{|c|}{$\begin{array}{l}\text { Touristic } \\
\text { strategy }\end{array}$} & \multicolumn{4}{|c|}{$\begin{array}{c}\text { Land management } \\
\text { strategy }\end{array}$} & \multirow{2}{*}{\multicolumn{2}{|c|}{$\begin{array}{c}\begin{array}{c}\text { Water use } \\
\text { strategy }\end{array} \\
\text { Water flow } \\
\left(\mathrm{m}^{3} / \text { year }\right)\end{array}$}} \\
\hline & & & \multicolumn{2}{|c|}{$\begin{array}{c}\text { Aesthetic value } \\
\text { (index) }\end{array}$} & \multicolumn{2}{|c|}{$\begin{array}{l}\text { Recreation }^{\dagger} \\
\text { (index) }\end{array}$} & \multicolumn{2}{|c|}{$\begin{array}{l}\text { Soil sealing } \\
\left(\mathrm{ha} / \mathrm{km}^{2}\right)\end{array}$} & \multicolumn{2}{|c|}{$\begin{array}{c}\text { Protected area } \\
(\% \text { of total area })\end{array}$} & & \\
\hline & Vent & Obergurgl & Vent & Obergurgl & Vent & Obergurgl & Vent & Obergurgl & Vent & Obergurgl & Vent & Obergurgl \\
\hline 1860 & 28.2 & 49.9 & 7.80 & 7.45 & 30.5 & 41.7 & 0.0099 & 0.0688 & 0 & 0 & 3472 & 9101 \\
\hline 1950 & 15.4 & 29.4 & 7.85 & 7.89 & 42.1 & 44.6 & 0.0490 & 0.1696 & 0 & 0 & 10,299 & 26,302 \\
\hline 1970 & 10.2 & 13.5 & 7.75 & 7.87 & 42.2 & 45.7 & 0.0641 & 0.3477 & 0 & 0 & 30,179 & 119,664 \\
\hline 2000 & 9.3 & 14.0 & 8.04 & 7.78 & 57.0 & 59.2 & 0.0670 & 0.3552 & 97.2 & 87.9 & 38,350 & 400,623 \\
\hline 2015 & 7.9 & 12.2 & 7.82 & 7.77 & 57.8 & 58.6 & 0.0772 & 0.4008 & 97.2 & 83.1 & 75,135 & 692,030 \\
\hline
\end{tabular}

higher values represent higher flows of the ES.

of farms in Vent increased from seven in 1990 to eight in 2016 (Data for 1990: Statistics Austria; Agricultural Structural Census; Data for 2016: Federal Ministry for Agriculture, Regions, and Tourism; Integrated Administration and Control System). Farmers have enmeshed agriculture with tourism through different forms of integration, e.g., the provision of accommodation, off-farm employment in tourism, compensation payments for touristic use of the land, or the provision of highquality food products for tourism. Currently, especially in Vent, the produce of many farms is sold directly, either to consumers, restaurants, or within their tourism facilities. These direct marketing strategies often depend on personal contacts with customers, e.g., in the Ötz Valley, and with professional providers, e.g., local restaurants (for details, see Stotten 2020a). However, the results of the survey (Fig. 3) show that the provision of food is considered to be of little importance to the residents of both Obergurgl and Vent. Although the consumption of agricultural products increased with the growth of the local population and of tourism (as seen for the example of beef, Table 5), no strategies were developed in either of the two villages to promote agriculture as a producer of local food products. Thus, meat production declined from 1860 to 2015 (Table 5).

In the 19th century, overproduction of meat was achieved in both villages (Fig. 4). Nevertheless, the applied agricultural strategy resulted in an outcome, where the supply of meat declined significantly: in Vent, the amount of meat needed to cover consumption at the local tourism structures, e.g., the mountain huts, can still be produced today, and farmers maintaining mountain huts often offer their produce in the menu there. In contrast, Obergurgl now imports $96.5 \%$ of its beef. This shows a lack of strategies to improve meat production in accordance with rising consumption, especially in Obergurgl. Also, local catering services do not encourage local meat production. The region showed a net export of beef (mostly calves) until the 19th century (Leiter 2016), but Obergurgl in particular and Vent to a lesser extent have become net importers of beef. Nevertheless, the additional income generated by tourism enables the inhabitants to continue costly and time-consuming agricultural activities, such as mowing steep slopes to maintain farming. Thus, the prevalent socio-cultural farming identity, mainly in Obergurgl, is detached from producing food, but instead is related to working the land and being a landowner. In contrast, the socio-cultural identity in Vent still relies on the production of food.
Fig. 4. The beef balance for the villages Vent and Obergurgl. Blue shading indicates the export of beef (supply $>$ demand), yellow shading indicates the import of beef (supply $<$ demand).

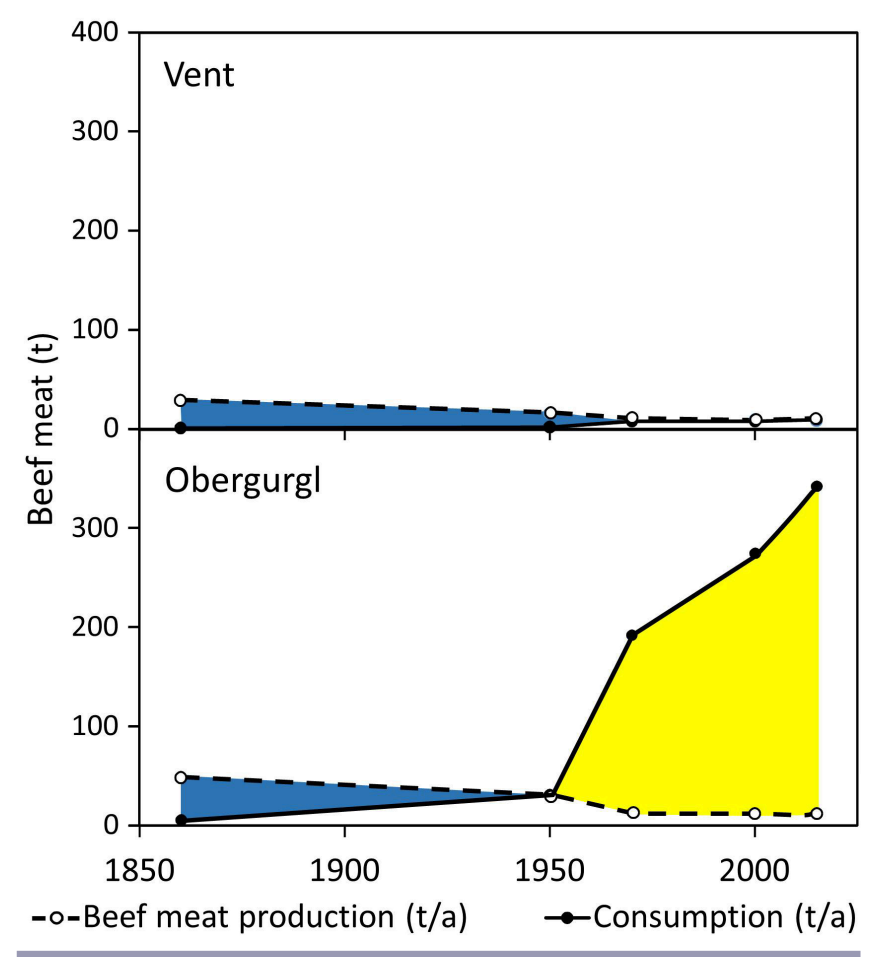

Touristic strategy and outcome

Tourism activities in Obergurgl and Vent have always been dominated by a few powerful actors (Stotten 2020b). Despite the touristic use of the local landscape, the inhabitants have long recognized the relevance of high aesthetic and recreation values to attract visitors and tourists. To make the areas of highest values accessible they expanded infrastructure, but the two villages set different priorities. In Obergurgl, a stronger focus is set on winter tourism. Local shareholders of the lift companies increased lift facilities to 25 in 2015 . The density of hiking trails and roads increased from $0.15 \mathrm{~km} / \mathrm{km}^{2}$ in 1860 to $1.55 \mathrm{~km} / \mathrm{km}^{2}$ in 2015 (Schirpke et al. 2019). The lift shareholders are also the owners of large upper-class hotels, whose goal is to increase ski resort 
Table 5. Beef demand in the villages Vent and Obergurgl for the five historical time steps.

\begin{tabular}{|c|c|c|c|c|c|c|c|}
\hline \multirow[b]{2}{*}{ Year } & \multicolumn{2}{|c|}{$\begin{array}{l}\text { Number of inhabitants } \\
\text { (n) }\end{array}$} & \multicolumn{2}{|c|}{$\begin{array}{l}\text { Number of overnight stays } \\
\text { (n/a) }\end{array}$} & \multirow[t]{2}{*}{$\begin{array}{c}\text { Beef consumption per capita } \\
\text { (kg/a) }\end{array}$} & \multicolumn{2}{|c|}{$\begin{array}{l}\text { Beef consumption total } \\
(\mathrm{t} / \mathrm{a})\end{array}$} \\
\hline & Vent & Obergurgl & Vent & Obergurgl & & Vent & Obergurgl \\
\hline 1860 & $50^{\mathrm{a}}$ & $131^{\mathrm{b}}$ & $16^{\mathrm{d}}$ & $55^{\mathrm{g}}$ & 12.5 & 0.6 & 6.6 \\
\hline 1950 & $100^{\mathrm{a}}$ & $212^{\mathrm{b}}$ & $11,600^{\dagger}$ & $40,000^{\mathrm{g}}$ & 12.5 & 1.6 & 32.2 \\
\hline 1970 & $155^{\mathrm{b}}$ & $333^{\mathrm{b}}$ & $67,000^{\mathrm{e}}$ & $333,000^{\mathrm{e}}$ & 22.97 & 7.8 & 193.0 \\
\hline 2000 & $139^{b}$ & $427^{b}$ & $99,000^{\mathrm{e}}$ & $569,000^{\mathrm{e}}$ & 19.1 & 7.8 & 276.0 \\
\hline 2015 & $146^{\mathrm{c}}$ & $492^{c}$ & $139,000^{\mathrm{f}}$ & $679,000^{\mathrm{f}}$ & 17.7 & 9.3 & 343.4 \\
\hline
\end{tabular}

${ }^{\mathrm{a}}$ Schlosser 2012, ${ }^{\mathrm{b}}$ Klein 2008, ${ }^{\mathrm{c}}$ Statistik Austria 2015, ${ }^{\mathrm{d}}$ Scharr 2013, ${ }^{\mathrm{e}}$ Haas and Weber $2008,{ }^{\mathrm{f}}$ E. Schöpf, 16 November 2017 , personal communication, ${ }^{\mathrm{g}}$ Patzelt 1989, h' Statistik Austria 2019

estimated based on the development in Obergurgl

capacity in winter to ensure the occupancy of their hotel beds. In contrast, there are also several small- and middle-sized bed and breakfast operations, whose owners have less power within the community. Efforts to strengthen the summer season are informally discussed, but no distinctive strategy is apparent for Obergurgl. Vent, however, positioned itself as a "mountaineering village" (ÖAV 2018) for "soft tourism" with a smaller number of guest beds and a more pronounced focus on summer tourism. The skiing infrastructure has not been expanded for a long time, and only a drag lift was recently replaced with a second-hand chairlift. In total, only four lifts existed in 2015. The inhabitants of Vent invested mainly in enhancement of the road and expansion of the hiking trail network (increased from $0.14 \mathrm{~km} / \mathrm{km}^{2}$ in 1860 to 0.81 $\mathrm{km} / \mathrm{km}^{2}$ in 2015 (Schirpke et al. 2019). Yet, hiking trail density in Vent is still significantly lower than in Obergurgl. Also, the ownership structure differs from that in Obergurgl. In Vent, the stakeholders of the lift company are farmers and thus also landowners. Furthermore, Vent has very few large hotels, and local tourism is based more on lower- and middle-class small- and medium-sized accommodation structures. Additionally, farm produce is often directly incorporated in accommodation services, which creates local food supply chains. The focus away from economic investments corresponds to Vent's soft tourism strategy.

As an outcome of the extreme focus on tourism in Obergurgl and Vent, both case study sites are economically dominated by tourism income. Detailed numbers for Obergurgl and Vent are not available, but the turnover of the five main tourism service providers (accommodation, gastronomy, ski lifts, ski schools, and sports article retailers) throughout the entire Ötz Valley (consisting of the six municipalities Sölden, Längenfeld, Umhausen, Ötz, Sautens, and Haiming) was nearly $€ 500$ million in 2015 . From 2005 to 2010 , the valley showed $36.1 \%$ growth in turnover (inflation-adjusted; Haselwanter et al. 2019), which underlines the valley's general focus on the tourism industry. However, this monostructural orientation of its economy also makes Vent and Obergurgl vulnerable. The focus on the winter season in Obergurgl results in seasonal outmigration to second homes that negatively influences social cohesion. Moreover, this phenomenon fosters possible future weakening of clubs and organizations and social services, which negatively affects social capital. The loss of social capital affects further cultural issues, e.g., declines in the importance of the church or traditional festivities. All this reinforces the shift in the sociocultural identity from a former farming community to a modern service-oriented community. In contrast to Obergurgl, the tourism strategy in Vent aligns with environmental issues (natural capital) and is less capital-intensive. Furthermore, the balance between the summer and the winter season permits active village life for approximately 9 to 10 months a year, which contributes positively to social cohesion. Here, the small number of residents is the limiting factor in building social capital. Additionally, the local food supply chains in Vent support the local economic circle. Expansion of touristic infrastructure in Vent and Obergurgl has affected the aesthetic and recreation value, with accessibility especially increasing at higher elevations, such as alpine pastures that are characterized by high aesthetic values. The recreation value shows a steady increase until 2015 (Table 4). With regard to the aesthetic value, however, the opposite of the intended effect was reached beginning in the 1970s; the increase in settlement area and the abandonment of pastures (natural capital) negatively affected the aesthetic value.

\section{Land management strategy and outcome}

Obergurgl has largely expanded its settlement area, road infrastructure, and the number of individual buildings ("rural sprawl"; Andexlinger 2015). Under Austrian law, the municipality of Sölden is the central planning authority and thus responsible for local spatial planning. Land development, however, has also been managed by designating protected areas. In 1977, a UNESCO biosphere reserve was designated in Obergurgl. However, because this reserve was established under pre-Seville conditions, the requirements were relatively low and skiing infrastructure was able to be established in the protected area. Faced with the impeding re-constitution of the UNESCO biosphere reserve (Seville Strategy of 2005), Obergurgl changed its strategy in 2014 and no longer supported the designation of larger areas with stricter conditions, but instead terminated the UNESCO biosphere reserve. The extent of the Ruhegebiet Ötztaler Alpen, however, has not changed since its establishment in 1981. Instead, stricter requirements have been added with the establishment of the Natura 2000 site in 1995. Although the inhabitants of Vent also expanded the settlement area, road infrastructure, and individual buildings, the built-up/sealed area remained smaller than in Obergurgl (Table 4). Vent also played an active role in conserving a traditional landscape by refusing to expand a ski resort (Hochjochferner) and connect it to a ski resort in South Tyrol (Schnalstaler Gletscher) in the 1990s (Scharr 2013). Since 1981, a large portion of the landscape has been continuously protected as a nature conservation area (it has also been a Natura 2000 site since 1995 and a Nature Park since 2006). 
As tourism strategy outcomes, the built-up/sealed area has increased in both Obergurgl and Vent (in Obergurgl to a greater degree). The agricultural area (used and potential) has thereby been reduced, and habitats have been lost and fragmented. Moreover, the inhabitants of Obergurgl decreased the share of the protected landscape to $83.2 \%$ of the total area (in Vent, it is still $97.2 \%$ of the total area, see Table 4) and ensured the continuation or new construction of skiing infrastructure (including roads, hotels, and lifts). Thus, they favored economic aspects at the expense of nature conservation and agricultural production.

\section{Water use strategy and outcome}

Considering the numbers of inhabitants and overnight stays, facilities for tourist accommodation and gastronomy have since the 1970s consumed more water than have the households (Table 6). Additionally, artificial snowmaking consumes huge amounts of water, especially in Obergurgl (Table 6). In Vent, water for artificial snowmaking is taken directly from one creek during the snowmaking season between November and March. The significantly greater water demand for snowmaking purposes in Obergurgl requires more infrastructure and regulations, e.g., in the form of water concessions granted by the state government. To cope with the water use regulations, lift operators in Obergurgl built artificial reservoirs that can be filled year-round and used for snowmaking in the winter months. Since 2015, two big reservoirs are operated in Obergurgl: the Wurmkogel reservoir has a usable storage volume of $82,800 \mathrm{~m}^{3}$ and the Schönwieshütte reservoir 49,500 $\mathrm{m}^{3}$. In 2021, the Festkogel reservoir with a usable storage volume of $39,900 \mathrm{~m}^{3}$ will go into operation. The volume of water naturally available in Obergurgl (1970: N.A., 2000: 134,170,646 $\mathrm{m}^{3}$, and 2015: 111,361,824 $\mathrm{m}^{3}$ ) and in Vent (1970: 97,452,288 $\mathrm{m}^{3}, 2000: 159,776,064 \mathrm{~m}^{3}$, and 2015: 142,218,029 $\mathrm{m}^{3}$ ) is significantly larger than water demand; the absence of water use strategies is legitimate and no negative outcomes can be noted (Table 6).

Table 6. Water demand in Obergurgl and Vent for the five historical time steps.

\begin{tabular}{|c|c|c|c|c|c|c|}
\hline & \multicolumn{2}{|c|}{$\begin{array}{l}\text { Water demand of } \\
\text { inhabitants }{ }^{\dagger}\left(\mathrm{m}^{3} / \mathrm{a}\right)\end{array}$} & \multicolumn{2}{|c|}{$\begin{array}{l}\text { Water demand for } \\
\text { tourist } \\
\text { accommodation } \\
\left(\mathrm{m}^{3} / \mathrm{a}\right)\end{array}$} & \multicolumn{2}{|c|}{$\begin{array}{l}\text { Water demand for } \\
\text { artificial snowmaking } \\
\left(\mathrm{m}^{3} / \mathrm{a}\right)\end{array}$} \\
\hline & Obergurgl & Vent & Obergurgl & Vent & Obergurgl & Vent \\
\hline 1860 & 9084.9 & 3467.5 & 16.0 & 4.6 & 0 & 0 \\
\hline 1950 & $14,702.2$ & 6935.0 & $11,600.0$ & $3,364.0$ & 0 & 0 \\
\hline 1970 & $23,093.6$ & $10,749.3$ & $96,570.0$ & $19,430.0$ & 0 & 0 \\
\hline 2000 & $29,612.5$ & 9639.7 & $165,010.0$ & $28,710.0$ & 206,000 & 0 \\
\hline 2015 & $34,120.2$ & $10,125.1$ & $196,910.0$ & $40,310.0$ & 461,000 & 24,700 \\
\hline
\end{tabular}

${ }^{\dagger}$ Number of inhabitants (see Table 2) multiplied by the mean daily water consumption of $190 \mathrm{~L}$ per day (Neunteufel et al. 2012).

${ }^{\ddagger}$ Number of tourists (see Table 2 ) multiplied by median water demand of 290 L per guest and day. Although we can suppose that the average hotel demand is lower in Vent than in Obergurgl because of differing hotel standards, we assumed the same water demand because of the lack of exact data.

${ }^{\S}$ We set water demand equal to the legal water concession according to the Tyrolean "Water Book" (Amt der Tiroler Landesregierung 2017).

\section{Evaluation of resilience}

Based on the livelihood strategies, the livelihood outcome feeds back on the individual capitals (Fig. 1). To illustratively evaluate the resilience of the investigated SES, the impact of given livelihood strategies and outcomes on the capitals was assessed. The status of the capitals in Obergurgl and Vent is quantified according to the evaluation of capitals (Table 3) and the influence of the four strategies is evaluated as follows:

Farming in Obergurgl (Table 3, agricultural strategy) significantly declined in economic importance; the traditional function of farming and the production of food also disappeared. The high demand for beef in Obergurgl, for example, is not covered by the local production possibilities. Meat needs to be imported, making the village more sensitive to external factors and decreasing its resilience. This local consumption of meat in tourism infrastructures could support local agriculture by providing a demand for local meat. In any case, farm household income relies on additional sources, such as land ownership and/or accommodation services. This additional income creates leeway for the farms so that adaptation strategies become possible and financially affordable. In this way, farms can respond to any disturbance and, more importantly, proactively strategize to keep the farms resilient (for details, see Stotten, 2020a). In Vent, farming (Table 3, agricultural strategy) also depends on public transfer and local payments for the touristic use of land. Moreover, the provision of accommodation services generates an important share of farm income. However, the synergies between farming and tourism are more intense than in Obergurgl as the touristic value of the cultural landscape seems to be more visible for summer tourism, and local food chains are intertwined with tourism. The farming identity is still strong in Vent (for details, see Stotten, 2020b); farming plays an important role in the prevailing type of soft tourism, even if Vent is far from being a farming village.

Although the touristic strategies (Table 3, touristic strategy) bring considerable income (especially in Obergurgl, Table 5), the touristic activities depend on the external labor force in both villages, a phenomenon that is more pronounced in Obergurgl than in Vent. The municipality of Sölden records a massive turnover generated by tourism, the high share of external labor leads to capital flow from the community to other regions or countries. Obergurgl's economic goals restrain the drive for natural capital. Furthermore, the wealth that many individuals in Obergurgl acquire from touristic incomes enables them to have a second home, which in effect weakens social cohesion and thus social and cultural capitals. However, the strengthening of economic capital, mainly by the tourism strategy, facilitates a gain in political power. Tourism further enabled the increase in aesthetic values at higher elevations because of expansion of the hiking trails and thus accessibility. However, the aesthetic and recreational outcomes overall decreased with time because of greater urban sprawl, abandonment of agricultural areas, and the loss of a biosphere reserve, thereby negatively influencing natural capital. In contrast, the moderate strengthening of economic capital by the tourism strategy in Vent leads to overall stronger resilience. Social cohesion functions better because residents are not wealthy enough to maintain a second home; the conflicting relationship between landowners (usually farmers) and the lift company is also far less pronounced than in Obergurgl. All of 
this also contributes to shared values among the villagers, which strengthens the cultural capital. However, the small number of residents limits the resilience of social and cultural capital.

A resilient SES has to maintain land for valuable ecosystem service provision (habitat, food, fodder, and recreation), but soil sealing increased in both Obergurgl and Vent (Table 3, land management strategy). The former rural character of Obergurgl has been obliterated, and potential farmland, as well as habitats for wild plants and animals, has decreased. The valley floor in Obergurgl is already densely built up, and consequently little potential remains for the construction of new tourist facilities. Therefore, the resilience of natural capital has been further lowered. In Vent, the sealed area is smaller and the share of protected areas is higher. Overall, human interference with the landscape and nature is kept to a minimum and in terms of the natural capital, resilience increases more than in Obergurgl. Regarding water use (Table 3, water use strategy), both villages are resilient. The high water demand for artificial snowmaking, however, makes the building of artificial reservoirs necessary in Obergurgl and changes the hydrological cycle from its natural condition, which weakens the resilience of the natural capital.

In summary, the H' indices (Table 3) in Vent are very balanced between 0.57 and 0.64 and are significantly higher than those in Obergurgl, especially in the case of agriculture and land management (2-tailed One-Sample Test: $p=0.001$ based on 1000 bootstrap samples). In summary, the $\mathrm{H}^{\prime}$ indices (Table 3 ) in Vent are very balanced between 0.57 and 0.64 and are significantly higher than those in Obergurgl, especially in the case of agriculture and land management. Thus, a higher overall socialecological resilience is evident in Vent. At the same time, this result also supports the fact that there are fewer trade-offs between the individual livelihood strategies in Vent.

\section{DISCUSSION}

\section{Social-ecological resilience of Obergurgl and Vent}

Evaluation of the social-ecological resilience as well as the differences between both communities has been illustrated above, where we revealed and described economic, social, cultural, political, and natural drivers and capitals. The evolution of resilience capitals differs greatly between Obergurgl and Vent and highlights the fact that the resilience of both communities is jeopardized more by several slow-onset disturbances, such as outmigration and social change, than by fast-onset disturbances such as natural hazards or global shocks. Our evaluation of the resilience finds Vent to be more resilient than Obergurgl, but possibly also more than other Alpine, tourism-based communities. Here, Vent has positioned itself as a winter and summer destination based on small-scale structures, which might be helpful in the long term when ski tourism decreases, and Vent has proved to cope better with the COVID-19 crisis in 2020 (observation by the authors in summer 2020).

In the qualitative data collection, both local communities considered themselves disconnected from macro-level (external) influences. This might be a phenomenon of lacking awareness rather than a real autonomy from externalities. Furthermore, respondents could hardly imagine any shocks because they were abstract at the time. However, the current COVID-19 crisis demonstrates that a disturbance can appear suddenly; the pandemic affected tourism in Tyrol especially hard (Bachtrögler et al. 2020). The perception of possible risks and shocks including causes, possible coping strategies, and the resulting consequences (Jurt Vicuña Muñoz 2009) are in both Obergurgl and Vent more focused on fast-onset disturbances such as avalanches, which especially for Vent have been harmful in the past. In contrast, slow-onset disturbances such as consequences of socioeconomic or climate change, are not actively addressed. Although climate change is considered a major issue jeopardizing resilience (Fuchs 2009, Luthe et al. 2012) and also Obergurgl and Vent are affected by it (see Tompkins and Adger 2004), the elevation of the two villages ensures temperatures that guarantee snow cover, either through precipitation or artificial snow. Therefore, no reactivity is needed immediately to keep the tourism industry running (see Steiger and Scott 2020). However, this missing consideration might cause problems in the long term.

\section{Strength and weaknesses of the novel framework and its application}

For application, the RLF integrates qualitative and quantitative social data as well as data from natural sciences. To address the concerns about the economic focus of the SRL framework (Acre 2003, De Haan 2012), the integrated concept of social-ecological resilience on a community scale applies the forms of capital from Bourdieu (1986). It gives crucial value to every capital and also considers interdependencies. It reflects the social embeddedness of economic action (see Granovetter 1985) as well as the cultural setting (Zelizer 2011). This improved the conceptualization of the resilience concept within the framework and contributes to its theoretical ground. However, the emphasis of individual capitals and thus their balance differs not only among different communities, but also within a community. In Obergurgl, major stakeholders strive for activities that favor economic capital, whereas in Vent, they highlight activities that respect natural capital. However, in each village there are also some inhabitants who do not support these activities.

Originally, the community resilience concept and the SRL framework considered all capitals as equal. In the novel RLF, we differentiated the natural capital from the economic, social, cultural, and political capital, thereby enhancing the consideration of ecological elements. From a human point of view, the environment is not only important in natural capital, but also contributes to human welfare through all capitals. Hence, we integrated the ES concept in the RLF. On the one hand, natural capital includes a set of critical and non-substitutable natural items satisfying basic needs ("critical natural capital"), which makes it fundamental to all other capitals. On the other hand, natural capital also supports "amenity services" that contribute but are not crucial to human well-being and could largely be substituted by manufactured services (Ekins et al. 2003). In both cases, natural capital is strongly influenced by its social valorization, e.g., recognition of climate change needed to launch measures, and is linked to and co-dependent with the other capitals (Potschin and Haines-Young 2011). Only through interaction with the other capitals can the natural capital in the RLF provide ES; in combination with the various livelihood strategies, the natural capital enables specific ES flows. These livelihood strategies are, inter alia, driven by ES demands. Our case study in Obergurgl highlights, for example, the fact that based on the natural capital a higher provision of beef (ES) would be 
possible and could at least partly cover the high consumption, but this is not demanded by the community because they prefer to import beef products. Hence, the agricultural livelihood strategy does not integrate the provision of beef. Contrastingly, in Vent the production volume of beef meets the consumption volume. Food self-sufficiency is often a component of resilient food systems, thereby contributing to a resilient SES (Wittmann 2011). The goal should not be to produce $100 \%$ of the food locally, but rather to increase the capacity to produce food, even if the region engages in food imports and exports (FAO 2015). In contrast, the aesthetic value of the landscape is another example of ES that is important for the tourism strategy (Pechlaner et al. 2007) and is recognized by the communities of both Obergurgl and Vent. Here, livelihood strategies were developed to maintain or even enhance the flow of "Aesthetic value." Therefore, the RLF shows the social valorization, the demand for certain ES, and the effects of the livelihood strategies arising therefrom.

Although we applied a modified Shannon-Wiener index to objectively evaluate social-ecological resilience based on capitals and livelihood strategies, the decision on how to integrate and rate the data rested with the researchers. Therefore, it is still partly subjective. Moreover, the four discussed livelihood strategies that determine the outcome were chosen by the authors on the basis of the issues that appeared to be important from the data and from the authors' expertise. The integration of other or further livelihood strategies could change the overall evaluation of socialecological resilience. This subjectivity has to be considered. However, the application of any framework demands a subjective decision (Kalu 2019). Finally, to evaluate the social-ecological resilience, we broke down the resilience of the two case study sites to a densified numerical value in order to bring all considered aspects into a final résumé. Certainly, not all information can be considered in this step. However, it serves to illustrate a densified outcome. We think the densified outcome and the background should serve as an information basis for further decisions regarding the livelihood strategies of both communities. For example, the intertwined complexities of the SES in Obergurgl and Vent result in similar consequences regarding the moderately social capital. There are, however, various underlying causes. In Obergurgl, wealth (strong economic capital) enables seasonal outmigration of the population, which weakens social capital. In Vent, the small number of residents endangers the social capital. So far, however, the economic activity in Vent is more strongly embedded in social (e.g., family networks) and cultural (e.g., farming traditions) aspects (see Granovetter 1985, Zelizer 2011) than in Obergurgl. This further explains the strong socio-cultural farming identity in Vent (see Stotten 2020b). Overall, Vent shows a stronger social-ecological resilience regarding the four investigated strategies than does Obergurgl.

The RLF is based on the elaborated framework integrating the concepts of community resilience and ES and provides a richly textured frame for understanding the subtleties of the resilience of an SES. The novel framework has the potential to reveal the social valorization and the social demand of a single ES. Here, we agree with Adger (2000) that social resilience, including economic, social, cultural, and political capital, depends on the ecological system and thus on the natural capital. Even if the original SRL framework was developed with a view to understanding the complexities of poverty in the Global South, the novel RLF enriched the framework and made it suitable for application in remote mountain areas. With emphasis on the natural capital and integration of the ES concept, we reveal complex interdependencies of social and ecological resilience.

\section{CONCLUSIONS}

By applying the RLF to case study sites in the Austrian Alps with combined sociological and ecological research approaches, we demonstrate how a detailed image can be drawn of the complex interplays of several drivers and capitals shaping the SES. Our case study area reveals that the complexities of an SES make it impossible to grasp all aspects in a schematization. Thus, the RLF strives to be holistic without claiming to be so. In the case studies, Vent showed stronger social-ecological resilience regarding the four investigated strategies than did Obergurgl. However, these results are subjective because of the methodological procedures and do not cover the full background information. Hence, to support management decisions and individual livelihood decisions within the community, we recommend transferring the full information about all external and internal drivers, the capitals, the livelihood strategies, and their resulting outcome, rather than only the densified outcome. The RLF might be a useful tool for investigation in other communities in the Alps because they have mostly experienced a substantial socioeconomic change in the last century and are furthermore affected by the impacts of climate change. The RLF provides a richly textured framework for understanding the subtleties of social, economic, and ecological challenges influencing the resilience and vulnerability of SES. We consider the RLF especially applicable in areas that are less globalized, more closely embedded in their physical environment, and thus strongly related to their natural capital. Moreover, the RLF is seen to also be able to capture gradual slow-onset disturbances that jeopardize resilience in many communities more than fast-onset disturbances.

Responses to this article can be read online at: https://www.ecologyandsociety.org/issues/responses. $\mathrm{php} / 12580$

\section{Acknowledgments:}

The authors wish to thank all our respondents in the Ötztal valley for their time and effort in participating in our research. They also wish to acknowledge very useful and constructive comments by the reviewers of this article. Further, the authors would like to thank Ika Darnhofer, Magnar Forbord, Johannes Rüdisser, Markus Schermer, and Geoff Wilson for valuable comments on earlier drafts of this paper. The Austrian Academy of Sciences (ÖAW) within the Earth System Science call project "RESilience through synergies between agricULTure and tourism: a comparison of two contrasting trajectories in the Tyrolean Alps" financially supported this work.

\section{Data Availability:}

The data that support the findings of this study are available on request from the corresponding author. None of the data are publicly 
available because of their containing information that could compromise the privacy of research participants.

\section{LITERATURE CITED}

Acre, A. 2003. Value contestations in development interventions: community development and sustainable livelihoods approaches. Community Development Journal 38:199-212. https://doi. org/10.1093/cdj/38.3.199

Adger, W. N. 2000. Social and ecological resilience: are they related? Progress in Human Geography 24:347-364. https://doi. org/10.1191/030913200701540465

Amt der Tiroler Landesregierung. 2017. Wasserbuch Tirol. Amt der Tiroler Landesregierung, Innsbruck, Austria.

Andexlinger, W. 2015. Alpine Urbanisierung. Transformation räumlicher Strukturen in Tirol. Habilitationsschrift, Universität Innsbruck, Innsbruck, Austria.

Bachtrögler, J., M. Firgo, O. Fritz, M. Klien, P. Mayerhofer, P. Piribauer, and G. Streicher. 2020. Regionale Unterschiede der ökonomischen Betroffenheit von der aktuellen COVID-19-Krise in Österreich. WIFO, Vienna, Austria.

Baker, S. 2007. Sustainable development. Routledge, London, UK.

Barker, M. L. 1982. Traditional landscape and mass tourism in the Alps. Geographical Review 72(4):395-415. https://doi. $\underline{\text { org/10.2307/214593 }}$

Bogner, A., B. Littig, and W. Menz. 2014. Interviews mit Experten. Eine praxisorientierte Einführung. Springer Fachmedien, Wiesbaden, Germany.

Bourdieu, P. 1986. The forms of capital. Pages 241-258 in J. G. Richardson, editor. Handbook of theory and research for the sociology of education. Greenwood, New York, New York, USA.

Bourdieu, P. 2016. Die feinen Unterschiede. Kritik der gesellschaftlichen Urteilskraft. Suhrkamp, Frankfurt am Main, Germany.

Burkhard, B., and J. Maes. 2017. Mapping ecosystem services. Pensoft, Sofia, Bulgaria. https://doi.org/10.3897/ab.e12837

Carney, D. 1998. Sustainable rural livelihoods: what contribution can we make? Department for International Development, London, UK.

Carpenter, S., B. Walker, J. M. Anderies, and N. Abel. 2001. From metaphor to measurement: resilience of what to what? Ecosystems 4:765-781. https://doi.org/10.1007/s10021-001-0045-9

Costanza, R., R. de Groot, P. Sutton, S. van der Ploeg, S. J. Anderson, I. Kubiszewski, S. Farber, and R. K. Turner. 2014. Changes in the global value of ecosystem services. Global Environmental Change 26:152-158. https://doi.org/10.1016/j. gloenvcha.2014.04.002

Cumming, G. S., G. Barnes, S. Perz, M. Schmink, K. E. Sieving, J. Southworth, M. Binford, R. D. Holt, C. Stickler, and T. van Holt. 2005. An exploratory framework for the empirical measurement of resilience. Ecosystems 8:975-987. https://doi. org/10.1007/s10021-005-0129-Z
Daskon, C., and T. Binns. 2010. Culture, tradition and sustainable rural livelihoods: exploring the culture-development interface in Kandy, Sri Lanka. Community Development Journal 45:494-517. https://doi.org/10.1093/cdj/bsp019

Davidson, D. J. 2010. The applicability of the concept of resilience to social systems: some sources of optimism and nagging doubts. Society \& Natural Resources 23:1135-1149. https://doi. org/10.1080/08941921003652940

Davoudi, S., K. Shaw, L. J. Haider, A. E. Quinlan, G. D. Peterson, C. Wilkinson, H. Fünfgeld, D. McEvoy, and L. Porter. 2012 Resilience: a bridging concept or a dead end? "Reframing" resilience: challenges for planning theory and practice interacting traps: resilience assessment of a pasture management system in northern Afghanistan urban resilience: What does it mean in planning practice? Resilience as a useful concept for climate change adaptation? The politics of resilience for planning: a cautionary note. Planning Theory \& Practice 13:299-333. https:// doi.org/10.1080/14649357.2012.677124

De Groot, R. S., M. A. Wilson, and R. M. J. Boumans. 2002. A typology for the classification, description and valuation of ecosystem functions, goods and services. Ecological Economics 41:393-408. https://doi.org/10.1016/S0921-8009(02)00089-7

De Haan, L. 2012. The livelihood approach: a critical exploration. Erdkunde 66:345-357. https://doi.org/10.3112/erdkunde.2012.04.05

Dorward, A. R. 2014. Livelisystems: a conceptual framework integrating social, ecosystem, development, and evolutionary theory. Ecology and Society 19(2):44. https://doi.org/10.5751/ ES-06494-190244

Dorward, A., N. Poole, J. Morrison, J. Kydd, and I. Urey. 2003. Markets, institutions and technology: missing links in livelihoods analysis. Development Policy Review 21:319-332. https://doi. org/10.1111/1467-7679.00213

Ekins, P., S. Simon, L. Deutsch, C. Folke, and R. de Groot. 2003. A framework for the practical application of the concepts of critical natural capital and strong sustainability. Ecological Economics 44:165-185. https://doi.org/10.1016/S0921-8009(02) $\underline{00272-0}$

Ellis, F. 1998. Household strategies and rural livelihood diversification. Journal of Development Studies 35:1-38. https:// doi.org/10.1080/00220389808422553

Emery, M., and C. Flora. 2006. Spiraling-up: mapping community transformation with community capitals framework. Community Development 37:19-35. https://doi.org/10.1080/155$\underline{75330609490152}$

European Environment Agency. 2015. Natura 2000 data - the European network of protected sites. EEA, Copenhagen, Denmark.

Farrington, J., D. Carney, C. Ashley, and C. Turton. 1999. Sustainable livelihoods in practice: early applications of concepts in rural areas. ODI, London, UK.

Fischer, A. 2014. Sustainable tourism. Haupt Verlag UTB, Bern, Switzerland.

Fischer, A., and A. McKee. 2017. A question of capacities? Community resilience and empowerment between assets, abilities 
and relationships. Journal of Rural Studies 54:187-197. https:// doi.org/10.1016/j.jrurstud.2017.06.020

Flury, C., R. Huber, and E. Tasser. 2013. Future of mountain agriculture in the Alps. Pages 105-126 in S. Mann, editor. The future of mountain agriculture. Springer, Berlin, Germany. https://doi.org/10.1007/978-3-642-33584-6 8

Folke, C., S. R. Carpenter, B. Walker, M. Scheffer, T. Chapin, and J. Rockström. 2010. Resilience thinking: integrating resilience, adaptability and transformability. Ecology and Society 15(4):20. https://doi.org/10.5751/es-03610-150420

Food and Agriculture Organization (FAO). 2015. Food selfsufficiency and international trade: a false dichotomy? FAO, Rome, Italy.

Forbes, B. C., F. Stammler, T. Kumpula, N. Meschtyb, A. Pajunen, and E. Kaarlejärvi. 2009. High resilience in the Yamal-Nenets social-ecological system, West Siberian Arctic, Russia. Proceedings of the National Academy of Sciences of the United States of America 106:22041-22048. https://doi.org/10.1073/ pnas.0908286106

Freshwater, D. 2015. Vulnerability and resilience: two dimensions of rurality. Sociologia Ruralis 55:497-515. https://doi. org/10.1111/soru.12090

Fuchs, S. 2009. Susceptibility versus resilience to mountain hazards in Austria - paradigms of vulnerability revisited. Natural Hazards and Earth System Sciences 9:337-352. https://doi. org/10.5194/nhess-9-337-2009

Granovetter, M. 1985. Economic action and social structure: the problem of embeddedness. American Journal of Sociology 91:481-510. https://doi.org/10.1086/228311

Gruber, C. 2019. Landschaft im oberen Ötztal: Wandel Wahrnehmung - Wertschätzung. Thesis. Universität Innsbruck, Innsbruck, Austria.

Gruber, M., A. Kanonier, S. Pohn-Weidinger, and A. Schindelegger. 2018. Spatial planning in Austria. With references to spatial development and regional policy. Austrian Conference on Spatial Planning (ÖROK), Vienna, Austria.

Haas, W., and M. Weber, editors. 2008. Endbericht MaB Biosphärenpark Ötztal (Phase 2). IFF Soziale Ökologie, Vienna, Austria.

Haines-Young, R., and M. B. Potschin. 2018. Common international classification of ecosystem services (CICES) V5.1 and guidance on the application of the revised structure. Fabis Consulting Ltd., Nottingham, UK. [online] URL: https://cices. eu/content/uploads/sites/8/2018/01/Guidance-V51-01012018.pdf

Haselwanter, S., M. Nadegger, B. Reitsamer, H. Siller, and J. Untersteiner. 2019. MCI Tourismus Destination research lab. MCI Tourismus, Management Center Innsbruck and Tirol Werbung GmbH, Innsbruck, Austria. [online] URL: https://www. ttr.tirol/sites/default/files/2019-07/2.1\%20MCI\%20Tourismus $\%$ 20Destination \%20Research\%20Lab.pdf

Hoffmann, N. 2018. Dokumentenanalyse in der Bildungs- und Sozialforschung. Überblick und Einführung. Beltz Juventa, Weinheim/Basel, Germany/Switzerland.
Huber, L., U. Schirpke, T. Marsoner, E. Tasser, and G. Leitinger. 2020. Does socioeconomic diversification enhance multifunctionality of mountain landscapes? Ecosystem Services 44:101122. https:// doi.org/10.1016/j.ecoser.2020.101122

Jacobs, P., and E. Makaudze. 2012. Understanding rural livelihoods in the West Coast District, South Africa. Development Southern Africa 29:574-587. https://doi.org/10.1080/0376835x.2012.715443

Jäger, H., G. Peratoner, U. Tappeiner, and E. Tasser. 2020. Grassland biomass balance in the European Alps: current and future ecosystem service perspectives. Ecosystem Services 45:101163. https://doi.org/10.1016/j.ecoser.2020.101163

Jurt Vicuña Muñoz, C. 2009. Perceptions of natural hazards in the context of social, cultural, economic and political risks. A case study in South Tyrol. Dissertation. University of Bern, Bern, Switzerland.

Kalu, M. E. 2019. How does "subjective I" influence a qualitative research question, theoretical approach and methodologies? Global Journal of Pure and Applied Sciences 25(1). https://doi. org/10.4314/gjpas.v25i1.13

Kelly, C., A. Ferrara, G. A. Wilson, F. Ripullone, A. Nolè, N. Harmer, and L. Salvati. 2015. Community resilience and land degradation in forest and shrubland socio-ecological systems: evidence from Gorgoglione, Basilicata, Italy. Land Use Policy 46:11-20. https://doi.org/10.1016/j.landusepol.2015.01.026

Klein, K. 2008. Historisches Ortslexikon (Tirol). Statistische Dokumentation zur Bevölkerungs- und Siedlungsgeschichte. ÖAW, Vienna, Austria.

Konopásek, Z. 2011. Das Denken mit ATLAS.ti sichtbar machen: Computergestützte qualitative Analyse als textuelle Praxis. Pages 381-403 in G. N. Mey, and K. Mruck, editors. Grounded theory reader. Springer Fachmedien, Wiesbaden, Germany. https://doi. org/10.1007/978-3-531-93318-4_17

Leiter, T. K. 2016. Tirol und der Donauhandel um 1700. University of Vienna, Vienna, Austria.

Luthe, T., R. Wyss, and M. Schuckert. 2012. Network governance and regional resilience to climate change: empirical evidence from mountain tourism communities in the Swiss Gotthard region. Regional Environmental Change 12:839-854. https://doi. org/10.1007/s10113-012-0294-5

Maclean, K., M. Cuthill, and H. Ross. 2014. Six attributes of social resilience. Journal of Environmental Planning and Management 57:144-156. https://doi.org/10.1080/09640568.2013.763774

Magis, K. 2010. Community resilience: an indicator of social sustainability. Society \& Natural Resources 23:401-416. https:// doi.org/10.1080/08941920903305674

Mayring, P. 2007. Qualitative Inhaltsanalyse. Grundlagen und Techniken. Beltz, Weinheim, Germany.

Meleghy, T., M. Preglau, and A. Tafertshofer. 1985. Tourism development and value change. Annals of Tourism Research 12:181-199. https://doi.org/10.1016/0160-7383(85)90056-8

Millennium Ecosystem Assessment. 2005. Ecosystems and human well-being: synthesis. Island, Washington, D.C., USA. 
Miller, F., H. Osbahr, E. Boyd, F. Thomalla, S. Bharwani, G. Ziervogel, B. Walker, J. Birkmann, S. Van der Leeuw, J. Rockström, J. Hinkel, T. Downing, C. Folke, and D. Nelson. 2010. Resilience and vulnerability: complementary or conflicting concepts? Ecology and Society 15(3):11. https://doi.org/10.5751/ es-03378-150311

Mishra, H. R. 2002. Mountains of the developing world: pockets of poverty or pinnacles for prosperity. Unasylva 53(208):18-24.

Morse, S., and N. McNamara. 2013. Sustainable livelihood approach. A critique of theory and practice. Springer Netherlands, Dordrecht, The Netherlands. https://doi. org/10.1007/978-94-007-6268-8

Neunteufel, R., L. Richard, R. Perfler, S. Tuschel, K. Mader, and E. Haas. 2012. Wasserverbrauch und Wasserbedarf. Auswertung empirischer Daten zum Wasserverbrauch. Bundesministerium für Land- und Forstwirtschaft, Umwelt und Wasserwirtschaft, Vienna, Austria.

New Zealand Nature Institute. 2006. Rural livelihoods and access to forest resources in Mongolia: methodology and case studies of Tsenkher Soum, Ulaan Uul Soum, Binder Soum, Teshig Soum and Baynlig Soum. FAO, Rome, Italy.

Österreichischer Alpenverein (ÖAV). 2018. Kleine und feine Bergsteigerdörfer zum Genießen und Verweilen. Innsbruck, Austria.

Paier, D. 2010. Quantitative Sozialforschung. Eine Einführung. Facultas WUV, Vienna, Austria.

Park, J., T. P. Seager, P. S. C. Rao, M. Convertino, and I. Linkov. 2013. Integrating risk and resilience approaches to catastrophe management in engineering systems. Risk Analysis 33:356-367. https://doi.org/10.1111/j.1539-6924.2012.01885.x

Patzelt, G., editor. 1989. 1889-1989. 100 Jahre Edelweiss. Die Geschichte des Hotels "Edelweiss \& Gurgl" in Obergurgl, Ötztal, Tirol. Eigenverlag Erich Scheiber, Obergurgl, Austria.

Pechlaner, H., F. Raich, and A. Zehrer. 2007. The Alps: challenges and potentials of a brand management. Tourism Analysis 12:359-369. https://doi.org/10.3727/108354207783228000

Plummer, R., and D. Armitage. 2007. A resilience-based framework for evaluating adaptive co-management: linking ecology, economics and society in a complex world. Ecological Economics 61:62-74. https://doi.org/10.1016/j.ecolecon.2006.09.025

Potschin, M. B., and R. H. Haines-Young. 2011. Ecosystem services: exploring a geographical perspective. Progress in Physical Geography 35:575-594. https://doi.org/10.1177/0309133311423172

Rivera, M., K. Knickel, J. M. Díaz-Puente, and A. Afonso. 2018. The role of social capital in agricultural and rural development: lessons learnt from case studies in seven countries. Sociologia Ruralis 59:66-91. https://doi.org/10.1111/soru.12218

Scharr, K. 2013. Vent. Geographie und Geschichte eines Ortes und seiner Täler. Wagner, Innsbruck, Austria.

Schirpke, U., A. Altzinger, G. Leitinger, and E. Tasser. 2019. Change from agricultural to touristic use: effects on the aesthetic value of landscapes over the last 150 years. Landscape and Urban Planning 187:23-35. https://doi.org/10.1016/j.landurbplan.2019.03.004
Schlosser, H. 2012. Alpingeschichte kurz und bündig. Vent im Ötztal. Österreichischer Alpenverein, Innsbruck, Austria.

Scoones, I. 1998. Sustainable rural livelihoods. A framework for analysis. IDS working paper 72. Institute of Development Studies, Brighton, UK.

Scoones, I. 2009. Livelihoods perspectives and rural development. Journal of Peasant Studies 36:171-196. https://doi. org/10.1080/03066150902820503

Scoones, I. 2015. Sustainable livelihoods and rural development. Practical Action, Rugby, UK. https://doi.org/10.3362/9781780448749

Small, L.-A. 2007. The sustainable rural livelihoods approach: a critical review. Canadian Journal of Development Studies 28:27-38. https://doi.org/10.1080/02255189.2007.9669186

Spellerberg, I. F., and P. J. Fedor. 2003. A tribute to Claude Shannon (1916-2001) and a plea for more rigorous use of species richness, species diversity and the 'Shannon-Wiener' Index. Global Ecology and Biogeography 12:177-179. https://doi. org/10.1046/j.1466-822X.2003.00015.X

Statistik Austria. 2015. Statistik des Bevölkerungsstandes. Statistik Austria, Vienna, Austria. [online] URL: https://www. salzburg.com/wiki/images/e/ea/Einwohnerzahl nach ortschaften 1.1.2015 gebietsstand 1.5.2015.pdf

Statistik Austria. 2017. Bevölkerung zu Jahresbeginn 2002-2021 nach Gemeinden. Statistik Austria, Vienna, Austria. [online] URL: https://www.statistik.at/wcm/idc/idcplg?IdcService= GET NATIVE FILE\&RevisionSelectionMethod= LatestReleased\&dDocName $=123069$

Statistik Austria. 2019. Wie viel Fleisch die Österreicher essen und warum es zu viel ist. Statistik Austria, Vienna, Austria. [online] URL: https://www.addendum.org/fleisch/fleischkonsumin-oesterreich

Steiger, R., and D. Scott. 2020. Ski tourism in a warmer world: increased adaptation and regional economic impacts in Austria. Tourism Management 77:104032. https://doi.org/10.1016/j. tourman.2019.104032

Stotten, R. 2020a. The role of farm diversification and peasant habitus for farm resilience in mountain areas: the case of the Ötztal valley, Austria. International Journal of Social Economics 48:947-964. [online] URL: https://www.emerald.com/insight/ content/doi/10.1108/IJSE-12-2019-0756/full/html

Stotten, R. 2020b. Tourismuseinwirkungen auf zwei Dörfer mit unterschiedlichen Entwicklungspfaden: Vent und Obergurgl (Tirol). Jahrbuch für Geschichte des ländlichen Raumes. Pages 116-132 in M. Knoll, editor. Cities - regions - hinterlands. Metabolisms, markets, and mobilities revisited. Jahrbuch für Geschichte des ländlichen Raumes/Rural History Yearbook 17/2020. Institute of Rural History, St. Pölten, Austria. [online] URL: https://journals.univie.ac.at/index.php/rhy/issue/view/394/75

Sulzer, U. 2018. Einfluss der Sozio-Ökonomie auf die Entwicklung der Landschaft in den Fraktionen der Gemeinde Sölden. Thesis. Universität Innsbruck, Innsbruck, Austria.

Tang, Q., S. J. Bennett, Y. Xu, and Y. Li. 2013. Agricultural practices and sustainable livelihoods: rural transformation within 
the Loess Plateau, China. Applied Geography 41:15-23. https:// doi.org/10.1016/j.apgeog.2013.03.007

Tasser, E., S. Aigner, G. Egger, and U. Tappeiner. 2013. Almatlas - Alpatlas - Atlante delle malghe. Arge Alp, Innsbruck, Austria.

Tasser, E., F. V. Ruffini, and U. Tappeiner. 2009. An integrative approach for analysing landscape dynamics in diverse cultivated and natural mountain areas. Landscape Ecology 24:611-628. https://doi.org/10.1007/s10980-009-9337-9

Tompkins, E. L., and W. N. Adger. 2004. Does adaptive management of natural resources enhance resilience to climate change? Ecology and Society 9(2):10. https://doi.org/10.5751/ es-00667-090210

van der Ploeg, J. D., H. Renting, G. Brunori, K. Knickel, J. Mannion, T. Marsden, K. de Roest, E. Sevilla-Guzmán, and F. Ventura. 2000. Rural development: from practices and policies towards theory. Sociologia Ruralis 40:391-408. https://doi. org/10.1111/1467-9523.00156

Vecco, M. 2010. A definition of cultural heritage: from the tangible to the intangible. Journal of Cultural Heritage 11:321-324. https://doi.org/10.1016/j.culher.2010.01.006

Villamagna, A. M., P. L. Angermeier, and E. M. Bennett. 2013. Capacity, pressure, demand, and flow: a conceptual framework for analyzing ecosystem service provision and delivery. Ecological Complexity 15:114-121. https://doi.org/10.1016/j.ecocom.2013.07.004

Walker, B., C. S. Holling, S. R. Carpenter, and A. Kinzig. 2004. Resilience, adaptability and transformability in social-ecological systems. Ecology and Society 9(2):5. https://doi.org/10.5751/ ES-00650-090205

Warren, C. R., R. Burton, O. Buchanan, and R. V. Birnie. 2016. Limited adoption of short rotation coppice: the role of farmers' socio-cultural identity in influencing practice. Journal of Rural Studies 45:175-183. https://doi.org/10.1016/j.jrurstud.2016.03.017

Wilson, G. 2010. Multifunctional 'quality' and rural community resilience. Transactions of the Institute of British Geographers 35:364-381. https://doi.org/10.1111/j.1475-5661.2010.00391.X

Wilson, G. 2012a. Community resilience and environmental transitions. Routledge, London, UK.

Wilson, G. 2012b. Community resilience, globalization, and transitional pathways of decision-making. Geoforum 43:1218-1231. https://doi.org/10.1016/j.geoforum.2012.03.008

Wilson, G. 2018. "Constructive tensions" in resilience research: critical reflections from a human geography. Geographical Journal 184:89-99. https://doi.org/10.1111/geoj.12232

Wilson, G., M. Schermer, and R. Stotten. 2018. The resilience and vulnerability of remote mountain communities: the case of Vent, Austrian Alps. Land Use Policy 71:372-383. https://doi. org/10.1016/j.landusepol.2017.12.022

Wittmann, H. 2011. Food sovereignty: reconnecting food, nature \& community. Pambazuka, Oxford, UK.

Zelizer, V. A. R. 2011. Economic lives. How culture shapes the economy. Princeton University Press, Oxford, UK.
Zucca, M. 2006. The Alps. The people: anthropology of small communities. Demographic movements. Women's condition. Development perspectives. Centro di Ecologia Alpina, Trento, Italy. 
Appendix 1. Resilience / Vulnerability context: Internal drivers on local capitals.

\section{Internal drivers influencing economic capital}

Tourism is the overarching economic activity in Obergurgl, directly as an employer, but also for indirectly supplying enterprises and firms (e.g., renovation and extension during the offseason and souvenir shop). Technical perfection of lifts, low waiting times, and snow security due to altitude are the strong points for attracting families and upper-class winter tourists. The attractiveness of the summer season is reduced by construction and maintenance works for big hotels. Construction work and the expansion of touristic facilities are thereby regulated by the local spatial planning of the municipality of Sölden. Lifts run only for two months in summer and make an economic loss because the number of visitors is low and there are only a few hotels open. There are three lift companies, each of which operate independently from the municipality and the tourism association. Their development goals are in line with their shareholders who are big hotel owners.

Although tourism developed out of a symbiosis with farming, today this connection is less prominent. Farmers benefit from the money they receive as compensation for touristic use of their land (e.g., transit rights, rights of use and easement agreements). This helps them to invest in farm implements. Direct marketing into tourism is mainly restricted to the use of products in its accommodation. Although many farmers offer accommodations, they are not tied to the farm; no farm offers 'Urlaub am Bauernhof' accommodation (farm holidays) (see also Stotten et al. 2019). Thus, farmers in Obergurgl profit from tourism more as landowners than as food producers or agri-tourism providers.

Economically, Vent has nearly balanced summer and winter seasons because it is mainly visited by mountaineers. Generally, the financial investments into new tourism infrastructure have been low. There are several alpine huts, often operated by local farmers, who use their own produce. One farmer is also offering accommodation and other farm activities through 'Urlaub am Bauernhof'. Public transfer payments and local payments for touristic use of land are also important parts of farm income. Overall, the synergies between agriculture and tourism are more intense than in Obergurgl; the touristic value of the cultural landscape also seems to be more visible for summer tourism. Therefore, the importance of farming for tourism is strongly recognized by the local population. Further, the symbiosis of tourism and agriculture enables short local food chains; this thinking is based more on closed economic cycles. For example, the inhabitants do not aim for economic expansion since it does not benefit the local population but rather attracts external workers. Among all the villages in Sölden municipality, Vent is regarded as the pioneer of sustainability and eco-tourism. However, this is also caused by the fact that they have been left behind for a long time in the collective marketing strategies of the municipality.

\section{Internal drivers influencing social capital}

The village life in Obergurgl is shaped by seasonal closures of hotels, restaurants, and infrastructure, as well as a seasonal outmigration of residents. This negatively influences the social cohesion and social services such as medical care. Further, professionalization in tourism prevents social interactions. Due to digitization and improved logistics, only a few local contacts are needed for professional hotel management such as marketing, procurement of food, or labor. However, social associations, especially the men's choir, play an important role in social cohesion. Women are weakly integrated into associations such as the fire 
brigade, ski club, and mountain rescue, so integration for them functions only via informal ways.

The population size of Vent has a critical size to actively shape village life. Since the 1990s, the church has not had a priest; however, it is still a central meeting point in Vent. The school had a critical size for many years, but it was closed in 2019. Also, associative life is becoming difficult in Vent. Few associations exist, but the members are often the same. In particular, residents want to take on less mandatory responsibility, making it more difficult to fill functions. With increased mobility and networking, younger people, in particular, commute to Sölden for specific associations (e.g., soccer), which also weakens local associations.

\section{Internal drivers influencing cultural capital}

The prevailing cultural identity in Obergurgl is a hybrid of farmer and tourism operator. The economic function of farming is strongly reduced, but it still has an important identification function, which contributes to the maintenance of traditional farming practices. Traditional festivities are not marketed to tourists and are still embedded in their religious context. Church activities, apart from social events like processions in spring, are more important for women because they are less represented in social associations. While the present generation that actively shapes economic activities still exhibits a traditional habitus, the next generation is more oriented towards economic growth and, thus, more inclined toward tourism. There is a tendency to shift the identity from being farmers to landowners who can counterbalance the power of lift operators.

In Vent, social identity as farmers is still strong; farming plays an important role in the prevailing type of eco-tourism, even if Vent is far from being a farming village. In Vent, the attachment to farming is also decreasing among youth. For farming identity, sheep breeding and relationship to South Tyrol play a major role. The local practice of transhumance of sheep from South Tyrol to their summer pastures is classified as a UNESCO intangible cultural heritage and is actively valued as a living tradition. This is also marketed as a tourist event on a small scale. The symbolic meaning of the church and Christianity, rather than the everyday practices of faith, still play a relatively large role in Vent.

\section{Internal drivers influencing political capital}

During 2016-2019, 4 of 15 members of the municipal council of Sölden came from Obergurgl, all of which were farmers. Obergurgl farmers are active in farming associations (e.g., gray cattle breeding association and the Haflinger World Association) and occupy official functions both historically and currently. This gives individual farmers access to specific knowledge, for example, regarding trends, new technologies, and good contacts outside the Ötztal Valley, such as the regional chambers of agriculture. The representation in the tourism association is restricted to few interrelated families who own large hotels and have shares on the lift operations (but do not own much land).

In Vent, two members are on the municipal council of Sölden, representing the group "Lebenswerte Heimat" that favors environmental aspects. The decision-making within the village mainly lies with the lift company, which is criticized by those running smaller bed and breakfasts who are not included in the decision-making processes. In contrast, the local committee of Ötztal Tourismus is open to suggestions and requests. Thus, the perceptions of a fair and democratic decision-making process differ among groups in the community. Within the village, the collectives of farmers (Agrargemeinschaften; see van Gils et al. 2014) organize the use of the alpine commons democratically. However, some farmers do not belong to the collective and cannot participate in decisions and discussions.

\section{Internal drivers influencing natural capital}


Obergurgl is less exposed to natural hazards and, as a consequence, there are few avalanches or flood hazards in the village. Also, the access road is less exposed to avalanche risk. Although there is no prevailing discourse on global warming, the first consequences of climate change are perceived, such as the breaking away of paths due to the decline in permafrost. However, due to the high altitude, the ski area of Obergurgl is still snow reliable. The maintenance of cultural landscape is considered important to avoid scrub encroachment of ski slopes and for summer tourism; however, the summer season is not strongly developed in the village. Further, the rural character in the village has been largely suppressed by the expansion of settlement areas at the expense of farmland and agricultural building structures in the village center. Additionally, the high volume of individual traffic also leads to additional construction (e.g., parking garages) and traffic in the village. Construction activities and, therefore, soil sealing are regulated by local spatial planning strategies.

Vent, in contrast to Obergurgl, has always been disadvantaged for skiing tourism; the steep slopes are threatened by avalanches and the access road to the village often needs to be closed due to high avalanche risk. However, the inhabitants have learned to see the low skiing infrastructure more of an opportunity than an obstacle; they have integrated 'sustainability' into their tourism approach. In the 1980s, for example, a connection of the skiing area with the neighboring valley was prevented by the local population for reasons of nature conservation. Today, the expansion of tourist facilities, such as bike trails, is viewed critically, concerning possible negative effects on the fauna. On an individual level, single hoteliers implement smaller ecological measures, such as avoiding waste (e.g., no single coffee cream or sugar packages), house sources of drinking water, and use of local meat products. In Vent, the consequences of global warming are perceived by the decline in permafrost. This triggers rock falls or landslides that affect the network of hiking trails, for example. So far, however, climate change has not been a major problem for Vent. It is still snow-reliable in winter but has only one small ski area. Concerning natural hazards, such as avalanches, Vent's access road is better protected today by avalanche barriers.

\section{LITERATURE CITED}

Stotten, R., M. Maurer, H. Herrmann, and M. Schermer. 2019. Different Forms of Accommodation in Agritourism: The Role of Decoupled Farmer-Based Accommodation in the Ötztal Valley (Austria). Sustainability 11:2841.

van Gils, H., G. Siegl, and R. Mark Bennett. 2014. The living commons of West Tyrol, Austria: Lessons for land policy and land administration. Land Use Policy 38:16-25. 